IJHER International Journal of Humanities and Educational Research ISSN: 2757-5403

Volume 4, Issue 1, February 2022

\title{
IMMUNITIES AND PRIVILEGES OF A DIPLOMATIC ENVOY
}

\section{Anwer Mohamed Ahmed ABUJANAH 1}

Dr, Bani Waleed University, Libya

\begin{abstract}
International diplomatic relations represent one of the greatest manifestations of independence and national sovereignty. This requires each autonomous state to establish various relationships with other countries. This leads, subsequently, to exchanges of ambassadors to manage foreign affairs.

It is of prime importance to highlight the significance of the preponderant role played by diplomatic representations in the development of international relations. This consequently justifies the privilege and the great assurance granted by States to representatives, and allows them to be more efficient in their representation.

This is why all States must ensure that the conditions of diplomatic agents are maintained, their rights are respected, as well as any act of deviation and violation of their assurances.

This study therefore proposes to highlight the concept of diplomatic immunity, with its various types and contexts, as an essential element in the practice of this profession.

It also aims to make explicit the regulations of the diplomatic system and the legal nature of the privileges granted to ambassadors.

Following the various changes recently produced in the international political arena, we consider it necessary to understand the challenges in the field and to study in as much detail as possible the security and guarantees possessed by the diplomatic agent.

This study is subdivided into four parts: We will first attempt to define the concept of diplomatic immunity,

And we explain, in a second place, the course and the historical development of the latter.

While the third part of the study, will be devoted to the explanation of the legal bases being at the origin of this immunity.

Finally, the fourth part will include the study of the various types of diplomatic immunity and their different manifestations.
\end{abstract}

Key words: Diplomacy, Diplomatic İmmunity, Diplomatic Envoy, Diplomatic Agents, Diplomatic Bag, Diplomatic Sector.

http://dx.doi.org/10.47832/2757-5403.12.11

1 (1) dranwer00@gmail.com, https://orc1d.org/0000-0002-1384-0987 


\title{
حصانات وامتيازات المبعوث الابلوماسي
}

\author{
أنور محمد أحمد أبو جناح \\ د، جامعة بن وليد، ليبيا
}

تعد العلاقات الدبلوماسية بين الدول من أهم مظاهر السيادة، إذ أن ظهور الدولة في مجال العلاقات الدولية يستتبع

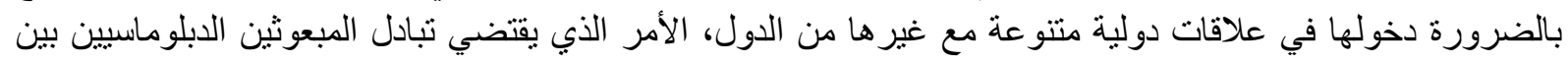
الدول لإدارة الثؤون الخارجية.

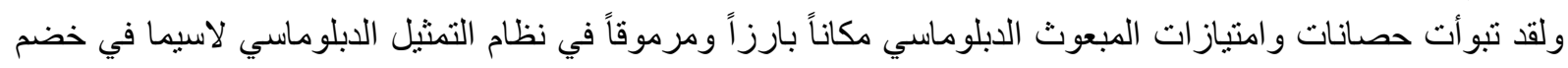

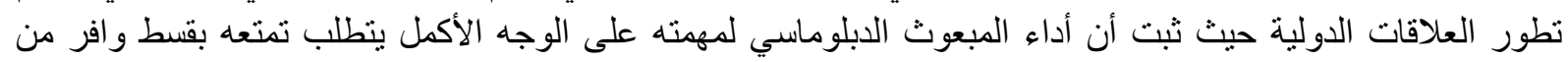

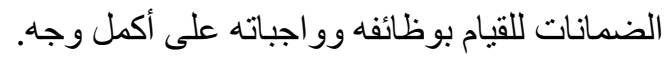

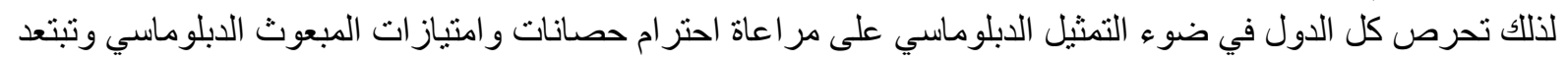

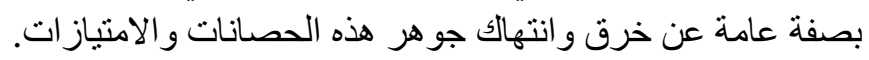

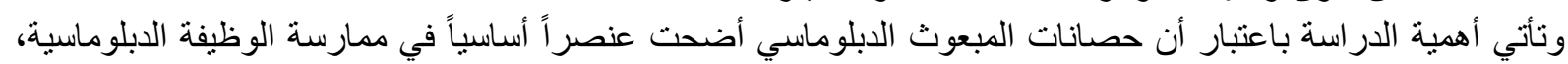

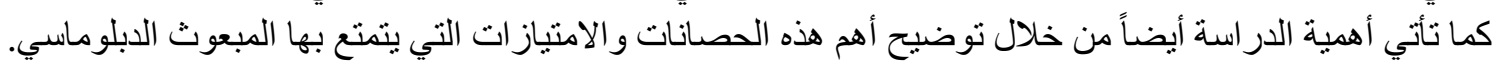

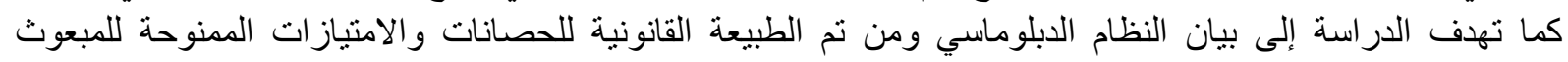
الدبلو ماسي.

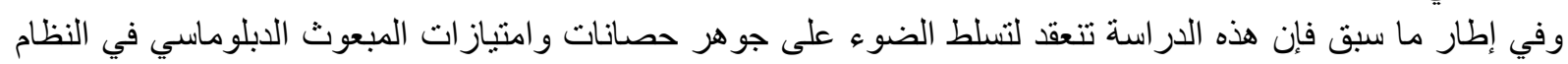

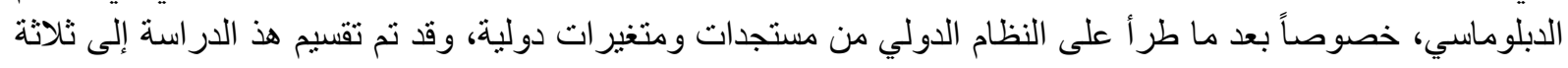

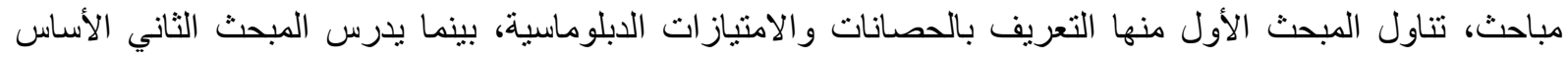

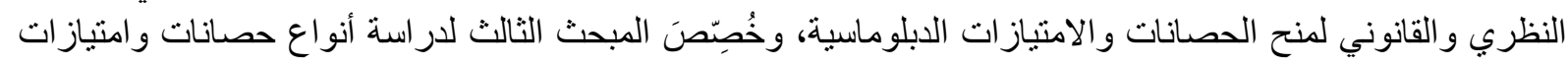

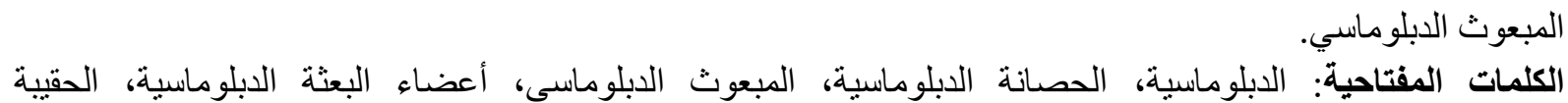
الدبلوماسية، السلك الدبلوماسي.

المقدمة:

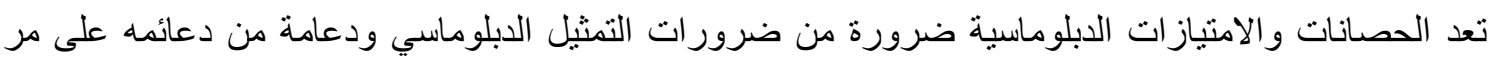

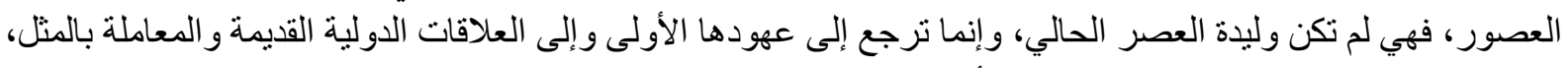

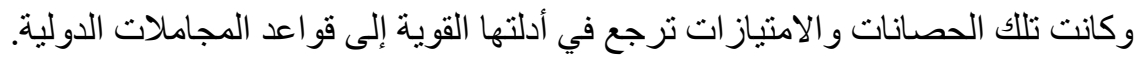

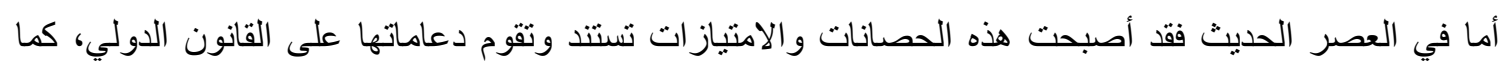

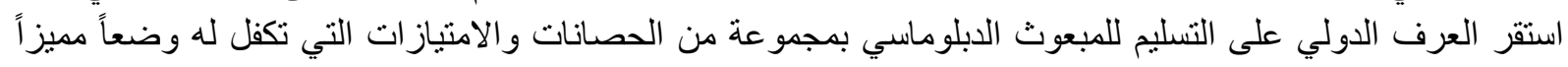

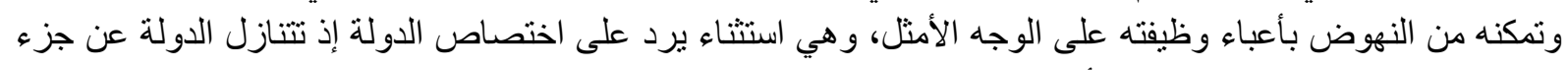
من سيادتها بهدف إعفاء بعض الأشخاص الذين يقع على عاتقهم القيام بالوظائف الدبلوماسية من سلطات الدولة الداء واختصاصها القضائي.

ولقد ارتبط مفهوم الحصانات والامتياز ات بمفهوم الدبلوماسية منذ بداية نشأة الدبلوماسية، فعلى مر العصور قدانية قديمها

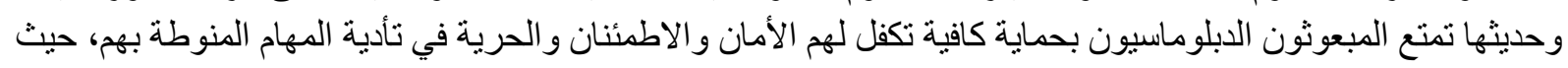

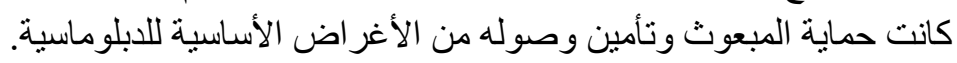

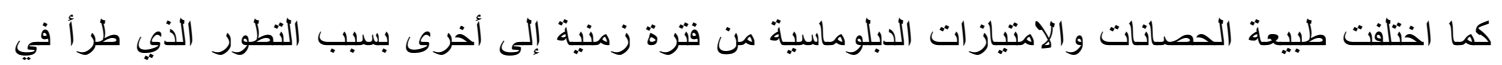

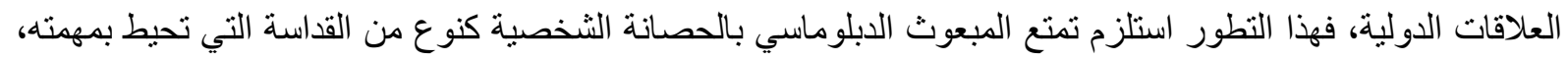

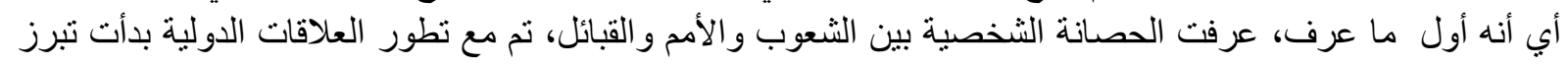


أهمية الحصانات والامتيازات للمبعوثين من أجل تأدية مهامهم على أكمل وجه وانتقلت من حماية دينية إلى تتريعات

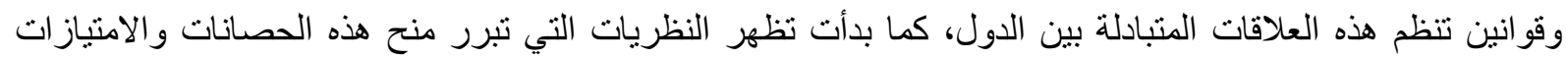

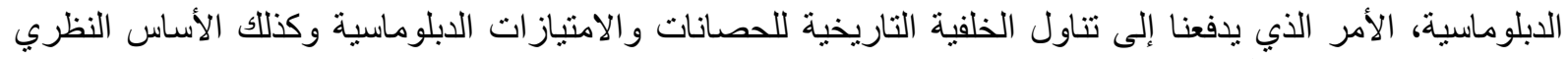

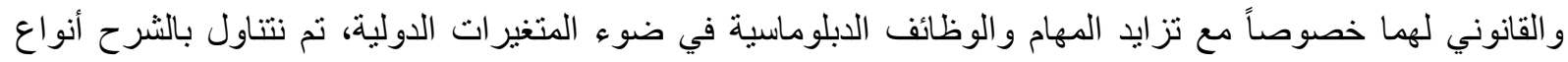
حصانات و امتياز ات المبعوث الدبلو ماسي.

\section{ولتوضيح ذلك اتبعنا الخطة المنهجية الآتية في تناولنا لهذه الاراسة:} 1- سبب اختيار موضوع الدراسة:

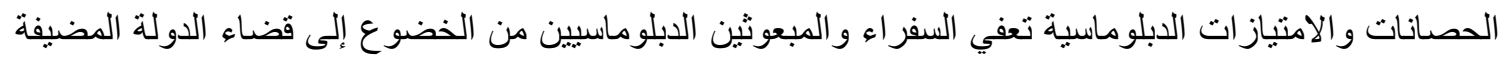

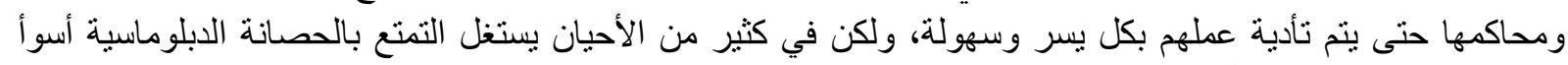

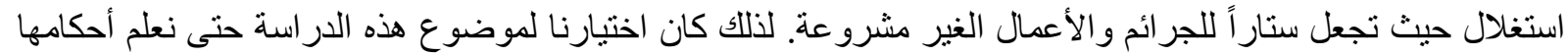

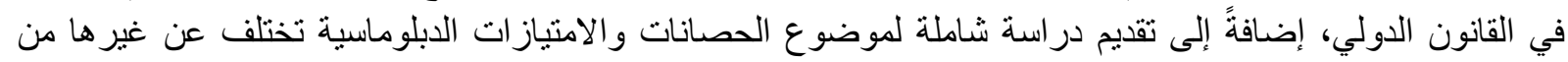

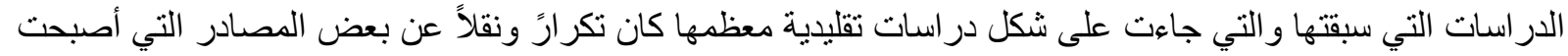

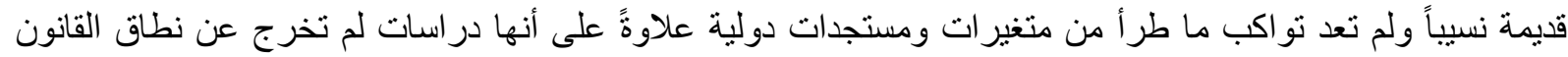

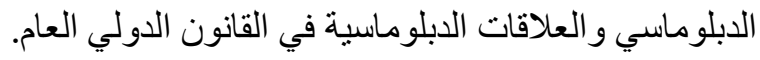
أما الدافع الثخصي فهو رغبة التعمق في هذا المجال من مجالات التنظيم الدبلوماسي ذي الصلة بالعلاقات السياسية الدولية وبالمسؤولية الدولية.

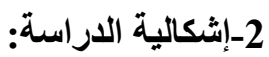

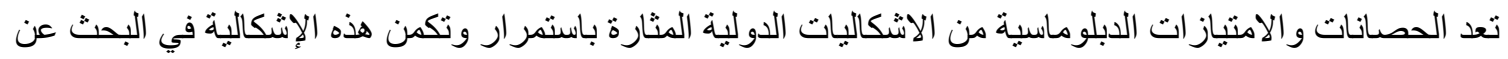

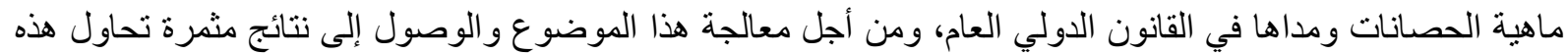
الدر اسة أن تجيب على التساؤلات الآتية:

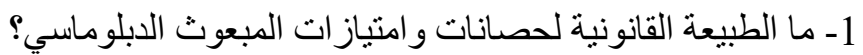

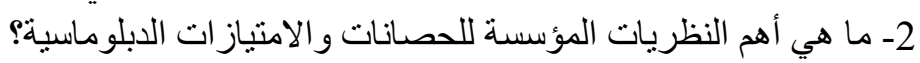

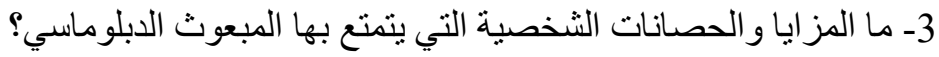

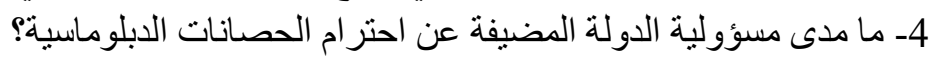

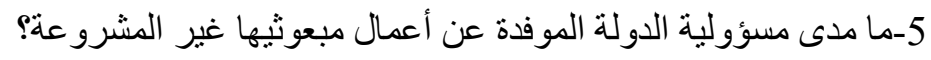

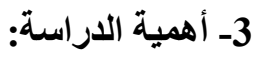

تكمن أهمية الدراسة من الناحية النظرية من أنها ستزودنا بالعديد من النتائج القانونية التي تساعدنا في توضيح

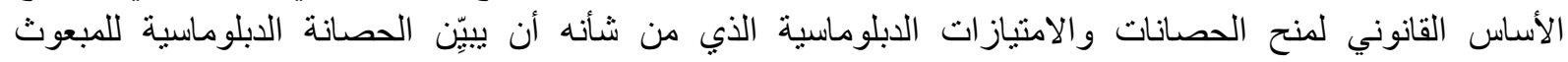

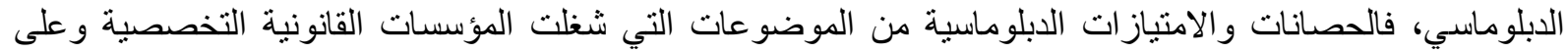

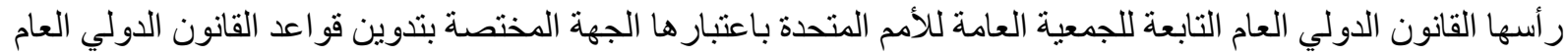
وتقنينه.

أما من الناحية العملية تنبع أهمية الدراسة لما ما للحصانات والامتيازات الدبلوماسية من ضرورة الدانة حتمية تمليها

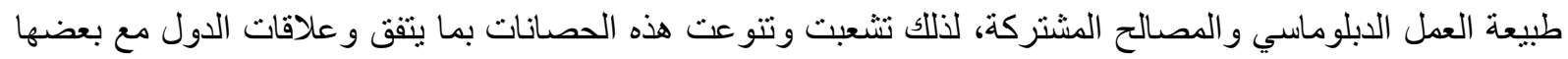

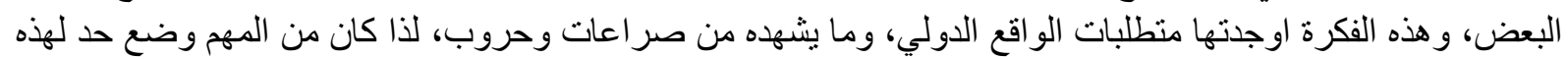

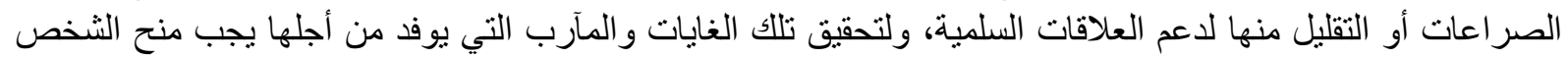

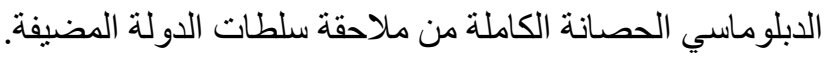

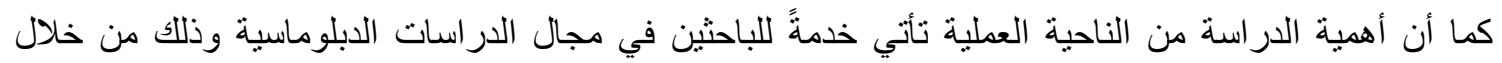

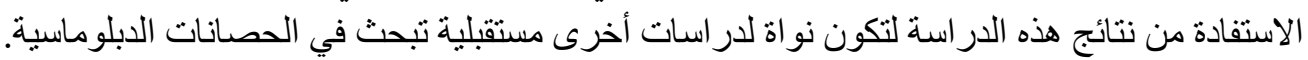


تهدف هذه الدر اسة لتحقيق جملة من الأهداف تتمثل فيما يلي:

1 -بيان ماهية الدبلوماسية بشكلٍ عام.

2-الوقوف على الأساس النظري و القانوني للحصانات و الامتياز ات الدبلوماسية. الممنوحة للمبعوث

3-تقديم در اسة مستفيضة عن التطور التاريخي للحصانات والامتياز ات الدبلوماسية.

4-الاسهام في تطوير نظام التمثيل الدبلوماسي وقو اعده.

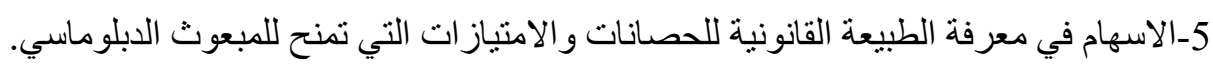

5- الحدود الزمانية والمكانية للاراسة:

- الحدود الزمانية: غطت هذه الدراسة الفترة الممتدة منذ زمن الإغريق مروراً بأحكام اتفاقية فيينا للعلاقات الدبلوماسية

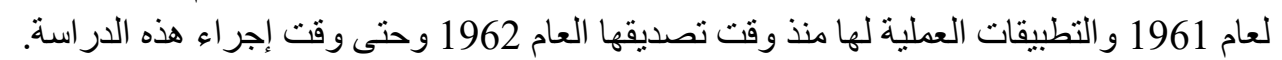

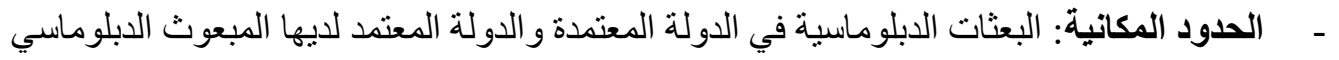

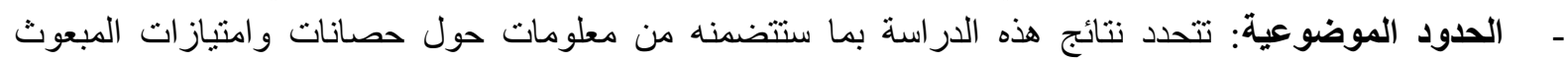

الدبلوماسي الثخصية والقانونية، و الأساس القانوني لمنح هذه الحصانات و الامنياز ات الدبلو ماسية.

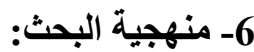

من المعلوم لكافة العاملين في مجال العلوم السياسية، أن هذه العلوم تنفرد بمجموعةٍ من المميز التهات مثل شمولية

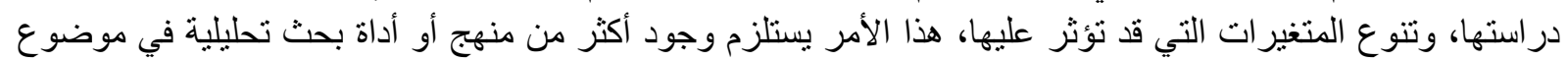

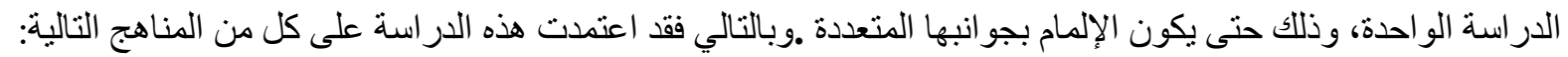

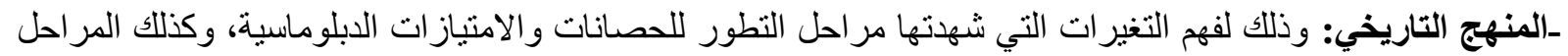

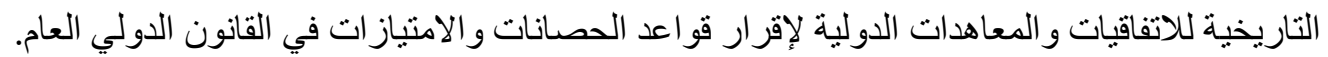

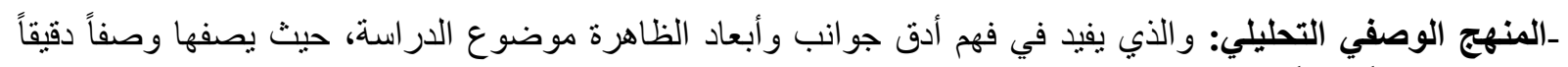
ويعبّر عنها كماً وكيفاً.

7- ميكلية الدراسة:

اقتضى البحث و الدر اسة في هذا الموضوع ضرورة أن يتم تقسيم هذه الدر اسة لأربعة مباحث هي كالتالي: 1-المبحث الأول: التعريف بالحصانات والامتياز ات الدبلوماسية. 2-المبحث الثاني: الأساس النظري و القانوني لمنح الحصانات و الامتياز ات الدبلوماسية. 3-المبحث الثالث: أنواع حصانات وامتيازات المبعوث الدبلوماسي. ولني. 


\section{المبحث الأول: تعريف الحصانات والامتيازات الدبلوماسية}

لللعريف بالحصانات و الامنياز ات الدبلوماسية تتطلب الضرورة منا التعرض لمعنى كل من الحصانة و الامتياز من حيث الدلالة اللغوية و الدلالة الاصطلاحية. أولاً: تعريف الحصانة لغةً واصطلاحاً: 1-نعريف الحصانة لغةً:

تشتق كلمة الحصانة (immunity) في اللغة الأجنية وخاصة الفرنسية من اللغة اللاتينية من كلمة (immunitas) وجذر ها (manus) وتعني الإعفاء من أعباء معينة (عبيد الله، 2001).

\section{ويشرح قاموس روبير الحصانة في عدة معان وهي (شابيش، 2010)}

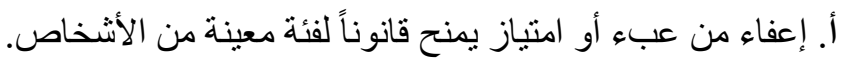
ب. الحصانة هي امتياز يمنح من الملك إلى ماللك كبير أو إلى مؤسسة كنسية، تقوم بمنح تصرف الأف الوكلاء المالكين في حقل هذا المالك الكبير.

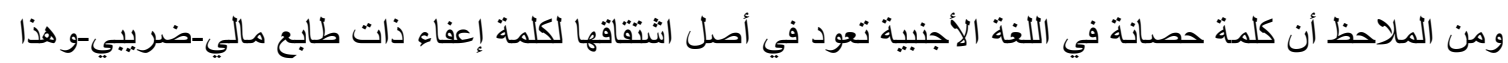
ما عنته الكلمة في القانون الروماني إذ أن جذر الكلمة (manus) هو الإعفاء من الأعباء البلدية ومن دفع الضراءئب وائ ومن

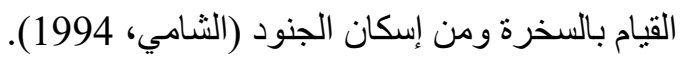

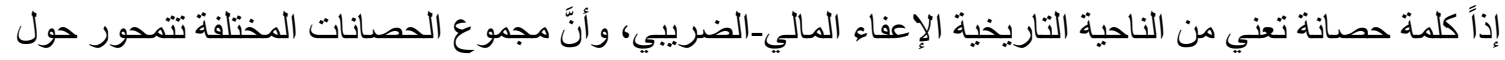

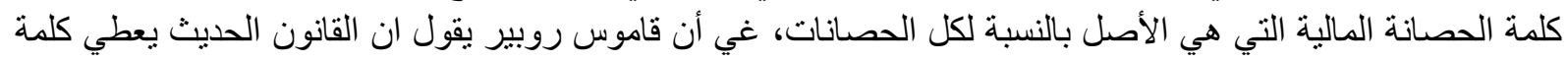

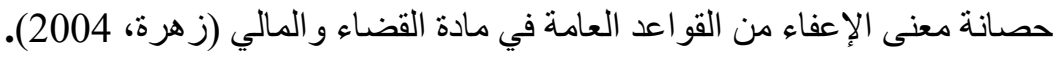

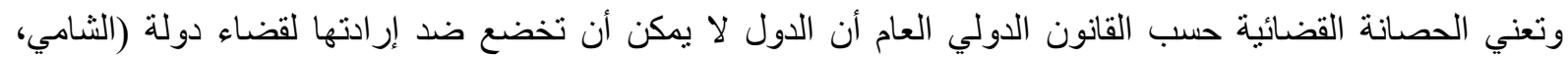

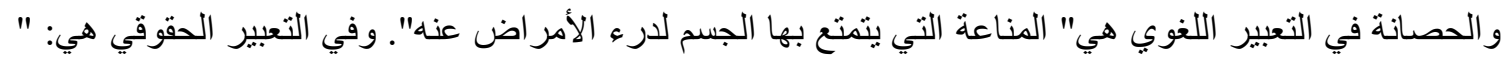

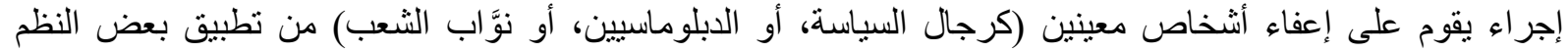

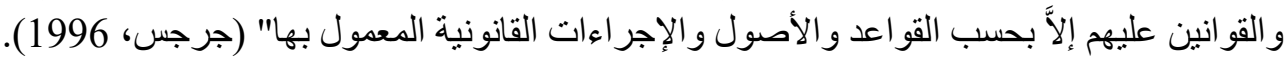

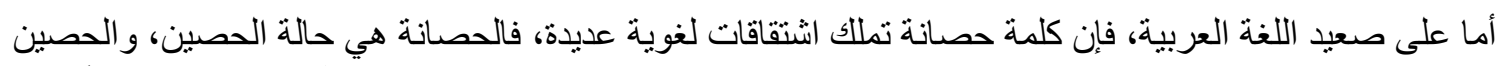

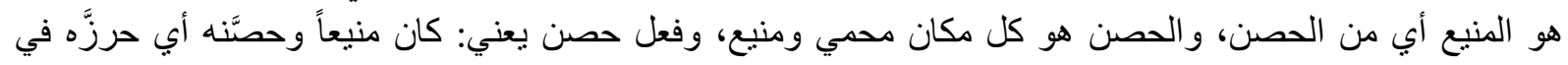
موضع حصين (الثامي، 1994).

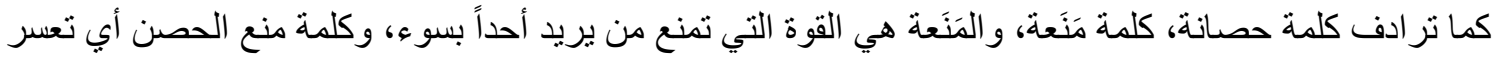

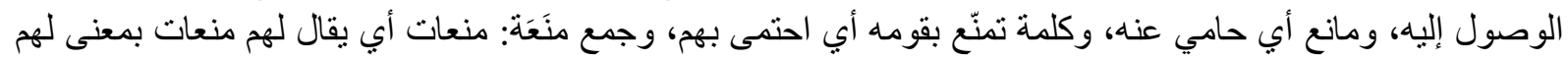

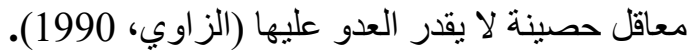
أما كلمة حرمة فهي مشتقة أيضاً من اللاتينية وتعني أنَّ شيئًا غير قابل للانتهاك أو أنه بستحيل انتهاكه أو خرقه بمعنى حق مقس لا ينتهاك (محمد، 1968). 2- تعريف الحصانة اصطلاحاً:

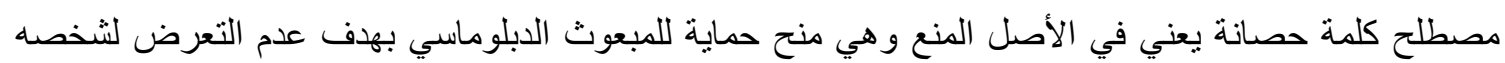
(جرجس، 1996) ، وكذللك عدم التعرض لذات المبعوث الدبلوماسي وحمايته من أي اعتداء يوجه إليه، واي فعل فيه

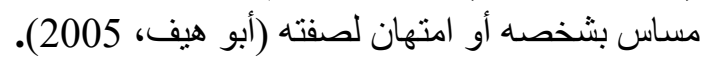

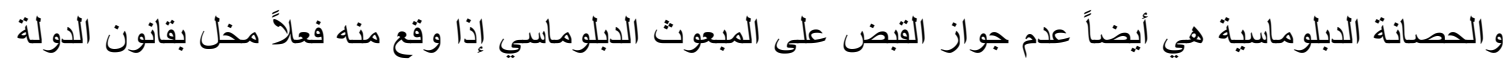
المبعوث لديها أو بسلامتها، و إنما تخطر دولته بذللك ويطلب إليها استدعاؤه ويجوز في الحالات القصوى تكليفه بمغادرة الإقليم على الفور (أبو هيف، 2005).

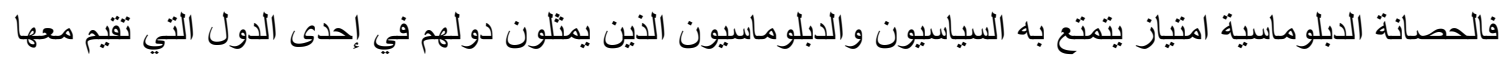

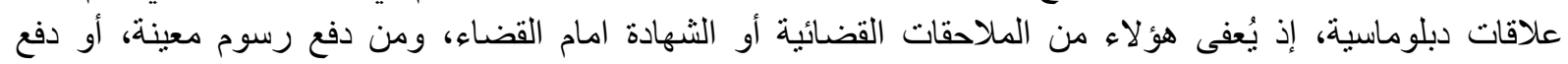

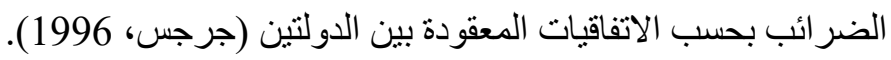




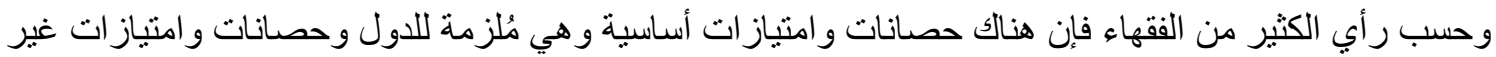

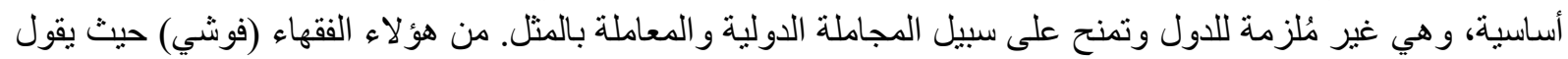

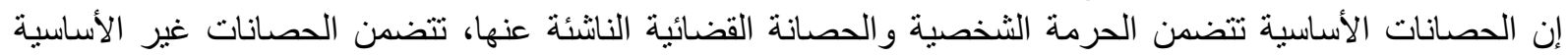

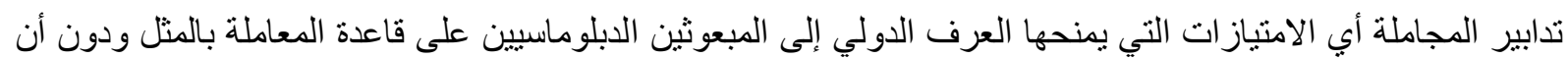

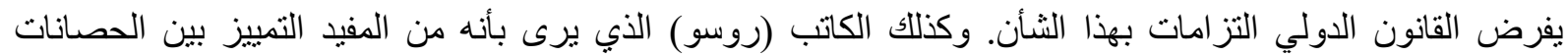
والامتيازات بالمعنى الدقيق" أي حرمة الثخصية والحصانة القضائية، والاعفاءات المالية، بين التسهيلات البسيطة

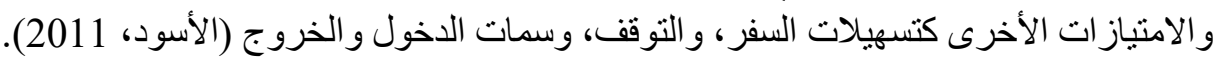

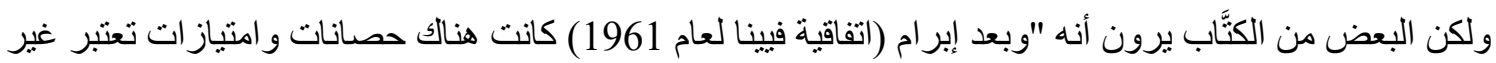

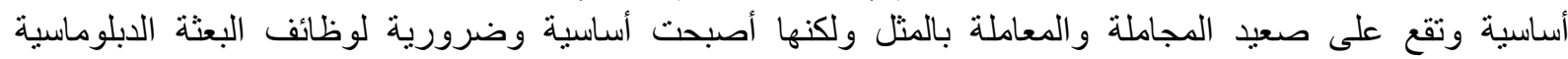

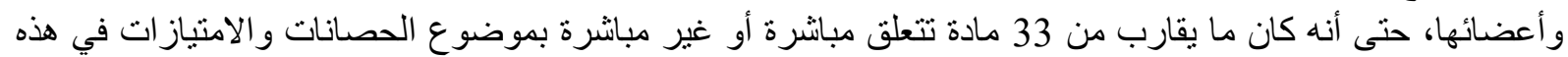

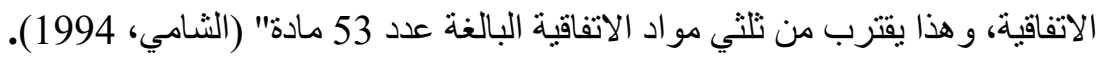

\section{ثانياً: تعريف الامتيازات لغةًً واصطلاحاً:

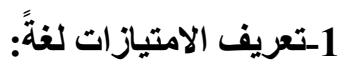

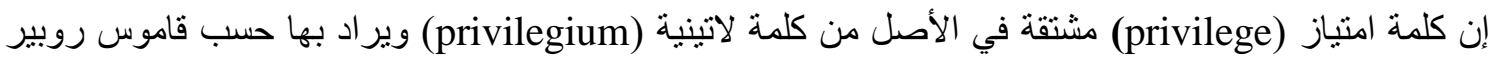

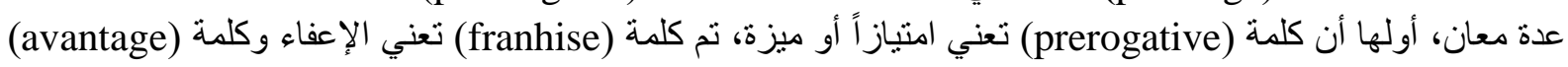

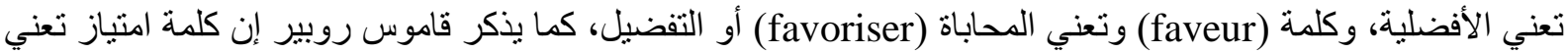

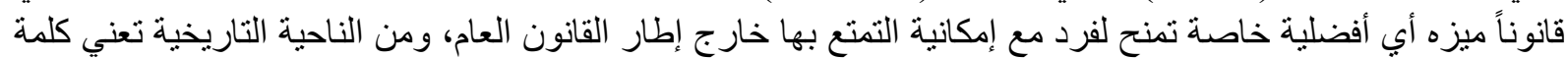

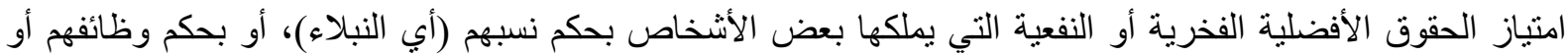
انخر اطهم في بعض (الهيئات القضائية) أو بعض الفعنة المناطق من إقليم الدولة (شابيش، 2010).

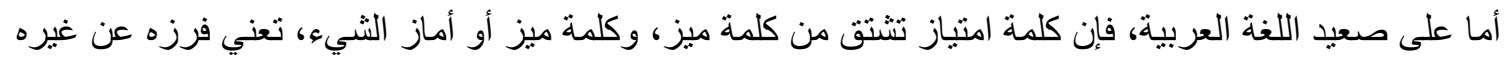

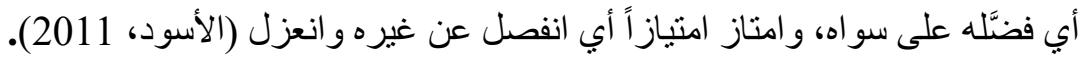

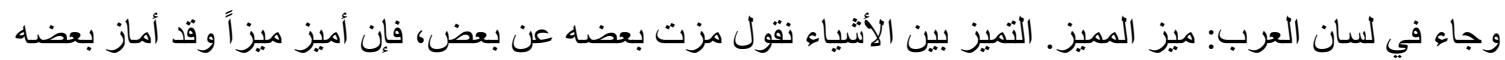
من بعض. ومزت الثيء أميزه ميزاً، وجاء في الحديث النبوي الثريف:" لا تهلك أمتي حتى يكون بينهم التماتل، و التمايز

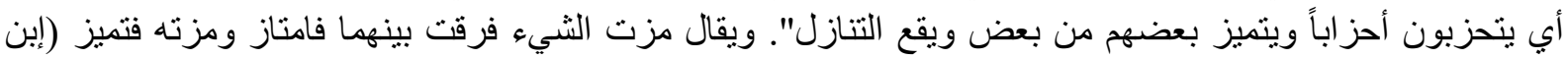
منظور، 2000).

\section{2-تعريف الامتياز ات اصطلاحاً:}

يقصد بهذا المصطلح: منح بعض المزايا المالية المتعلقة بالإعفاء من الضرائب والرسوم الجمركية (الثامي، 1994)، تسمح هذه الإعفاءات للمبعوث الدبلو ماسي بتأمينه وتحقيق أهداف مهنته.

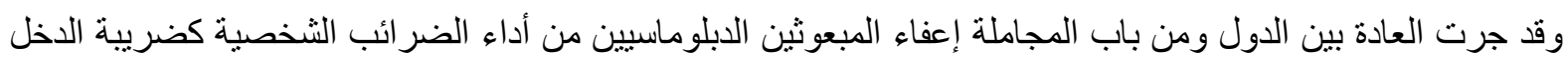

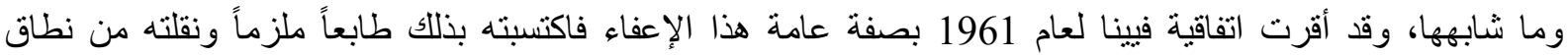

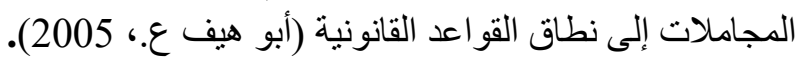

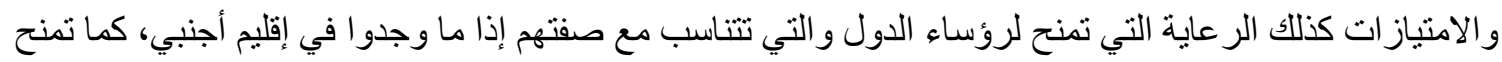
لوزر اء الخار جية وللممثلين الدبلوماسيبين (السامر ائي، 2002).

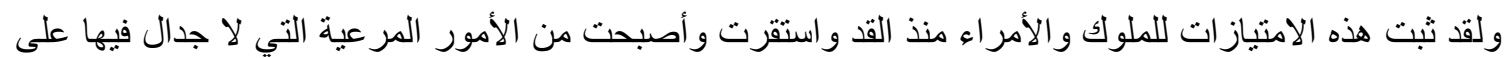

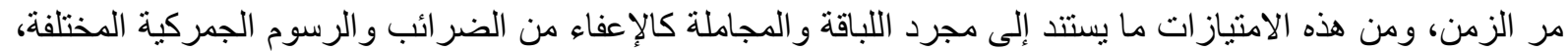

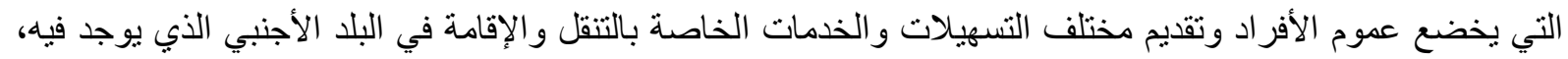
ومنها ما هو نتيجة قانونية لما تتمتع به الدولة التي يمثلها من سيادة وسلطان، ويقتضيان مر اعاة حرمة ذاته ومسكنه و وعدم

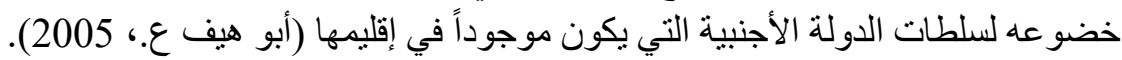

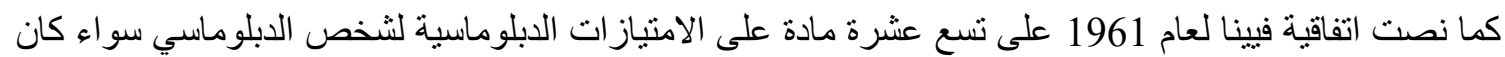

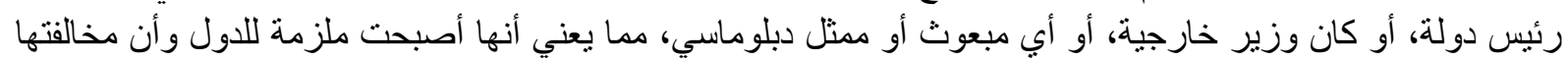


تترتب عليه مسؤولية دولية واضحة، حيث كانت هذه الامتيازات تمنح على أساس المجاملة الدولية والمعاملة بالمثل، فأصبحت اليوم ملزمة لكل الدوله

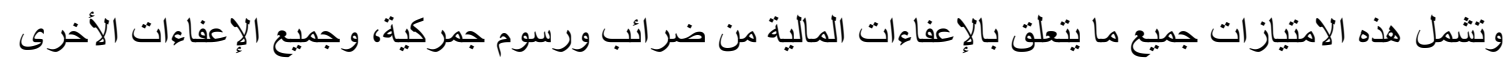

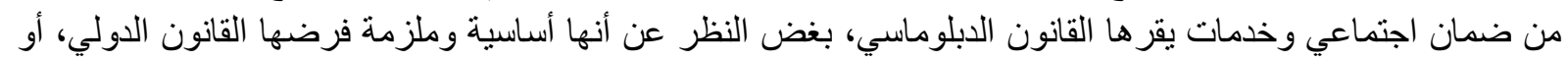

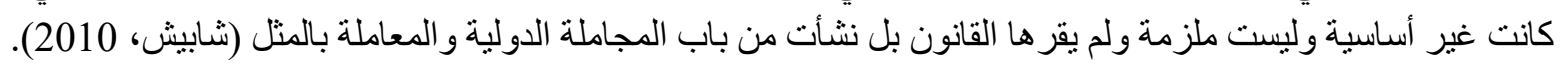

ثالثاً: تعريف الدبلوماسية لغةًً واصطلاحاً: 1-تعريف الدبلوماسية لغةً:

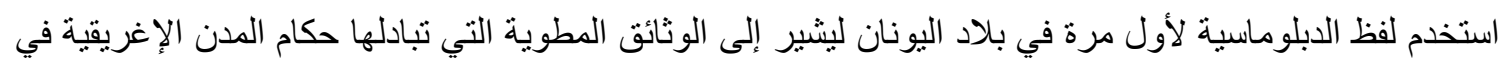

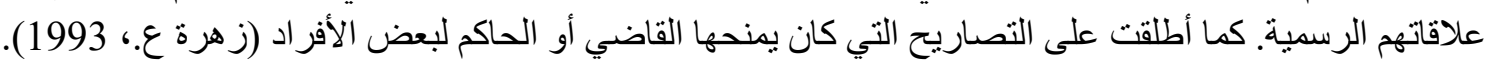

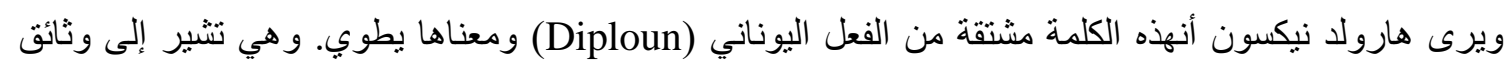

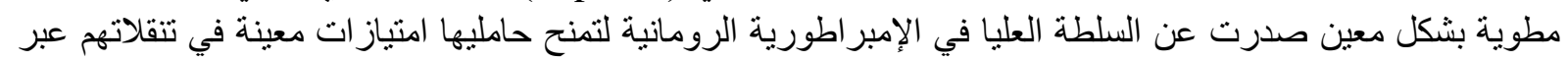

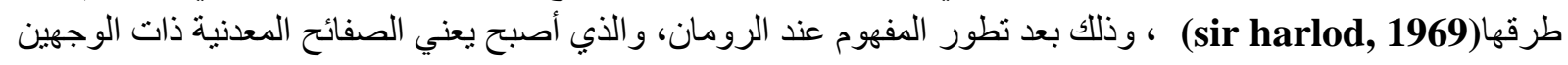

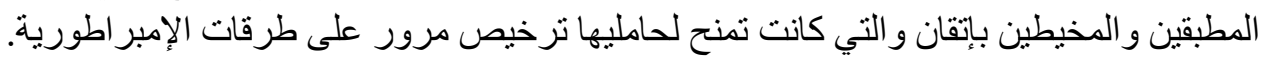

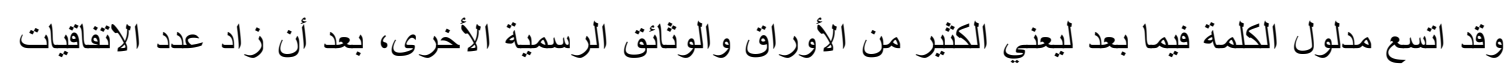

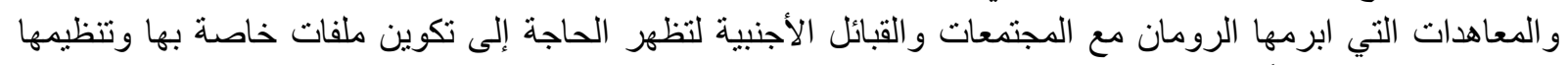
وحفظها، وليظهر تبعاً لذلك موظفون مختصون مهنتهم التبويب وفهرسة التهان تلك الوثنائق وهم ما يعرفون اليوم بأمناء المحفوظات (زهرة ع. ولنه 1993).

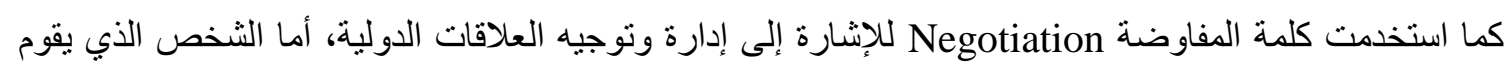

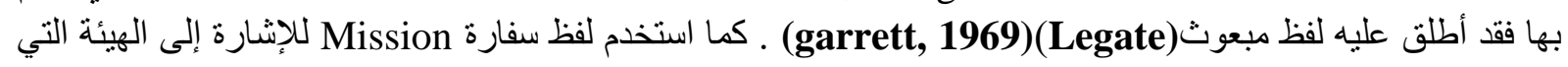

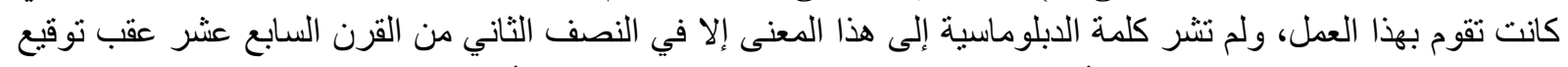

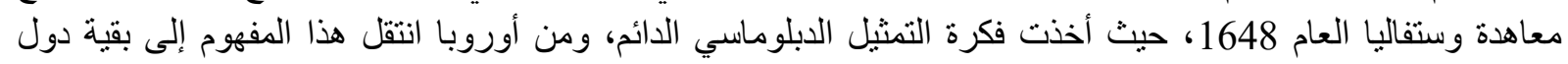
العالم. ميعاهد.

أما على صعيد اللغة العربية فلا توجد لكلمة دبلوماسية ترجمة حرفية مقابلة لها، فقد استخدم العرب كلمنين للتعبير

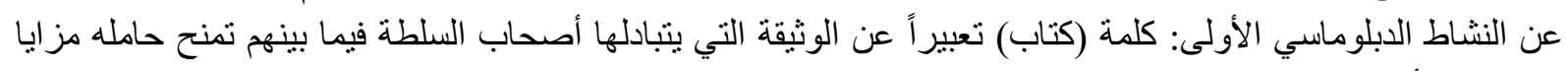

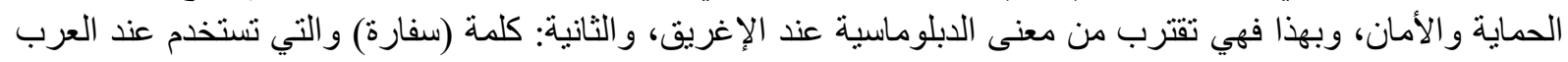

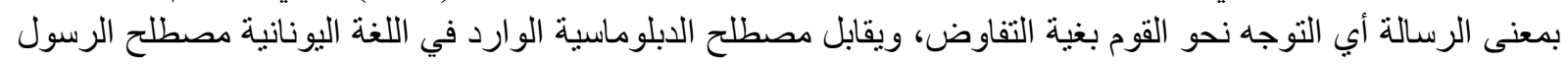

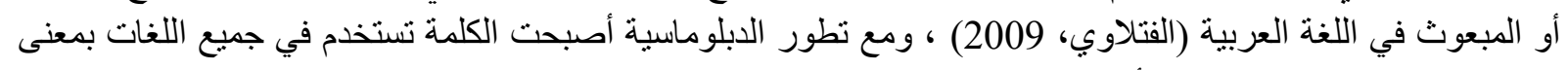

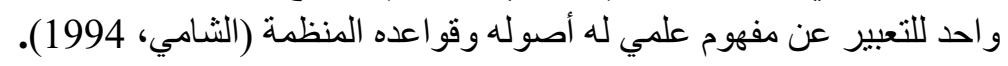
2-تعريف الابلوماسية اصطلاحاً:

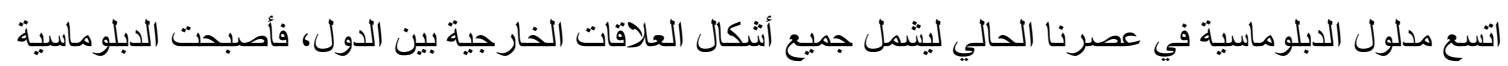

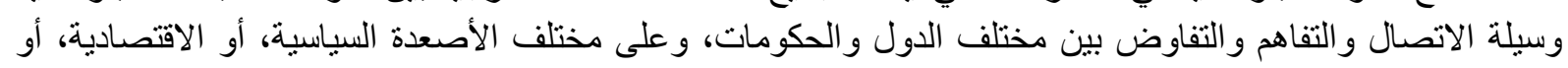

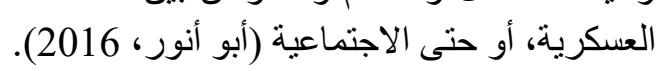

و هناك مجمو عة من التعريفات لمصطلح الدبلوماسية التي تناو لها الكتاب ومنها: 1-تعريف قاموس أكسفورد للغة الإنجليزية بأنها " تصريف شؤون العلاقات الدولية عن طريق المفاوضات" (الهانمي،

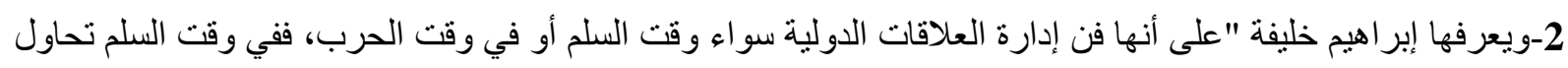

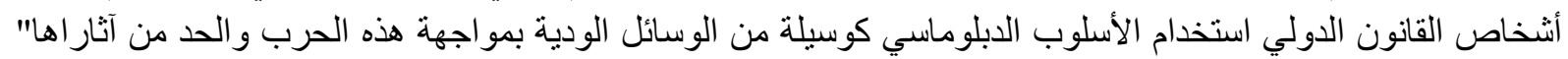
(خليفة، 2007).

3-أما حسن صعب فيعرف الدبلوماسية بأنها "علمُ وفنٌ وقانونٌٌ وتاريخٌ ومؤسسةٌُومهنةٌ" (أبو عامر، 2004). 
4-ويعرفها راؤول جينيه بأنها:" فن تمثيل الحكومة، ور عاية مصالح الدول لاى بلد أجنبي، ويتضمن هذا السهر على احترام حقوق مصالح الدولة، وإدارة العلاقات الخارجية طبقاً للتعليمات المرسلة بالقيام بالمفاوضات الداتي، الدبلوماسية (صباريني، .2011

ومن خلال التعريفات السابقة نلاحظ أن مفهوم الدبلو ماسية يختلف من مفكر لآخر ، حيث عدها البعض علماً، والبعض الآخر فناً، في حين جمع آخرون بين الإثثين معاً. 


\section{المبحث الثاني: الأساس النظري والقانوني للحصانات والامتيازات الابلوماسية:}

أولاً: الأساس النظري للحصانات والامتيازات الابلوماسية:

بحث فقهاء القانون الدولي عن الأساس النظري الذي يفسر الحصانات والامتيازات الدبلوماسية، وظهرت عدة

نظريات، أهمها ثلاث نظريات هي:

1-نظرية التمثيل الثخصي "الصفة التمثيلية": انتشرت هذه النظرية في القرن الثنامن عشر إبان النظام الملكي في أوروبا (صباريني، 2011)، ويعتبر الفقيه الفرنسي مونتسكيو أول من نادى بهذه النظرية، مفادها أن الحصانات و الامتيازات فئان

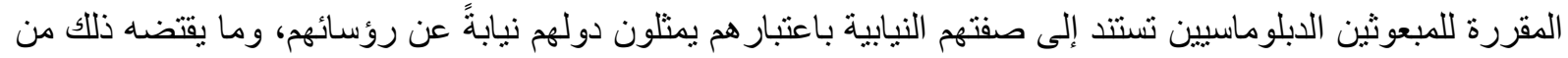

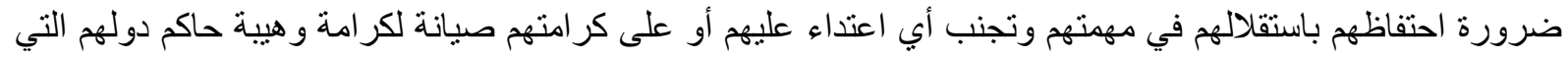
يمثلونها. وأخيراً، فإنه في الوقت الحاضر، فإن المبعوث الدبلوماسي لا يمثل الملك ولكن الدولة بكاملها ككيان سياسي وقانوني

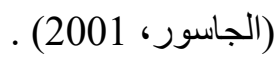

وقد تعرضت هذه النظرية للنقد لأنها لا تفسر إلا الحصانات والامتياز ات التي يتمتع بها المبعوث الدبلوماسي للقيام

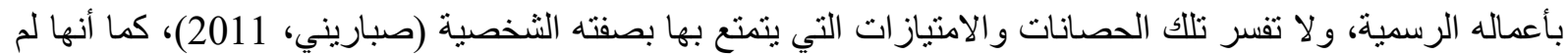

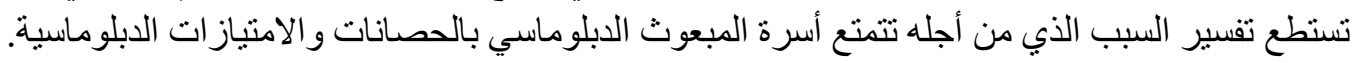

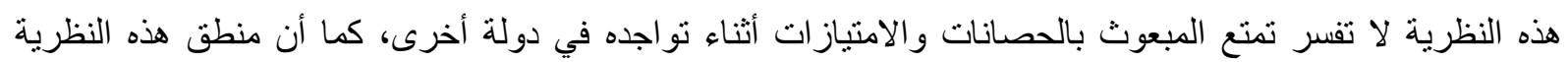

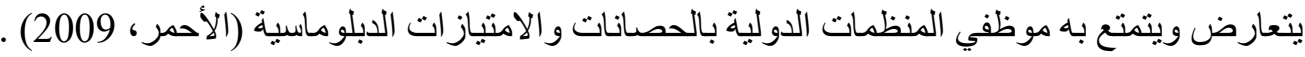

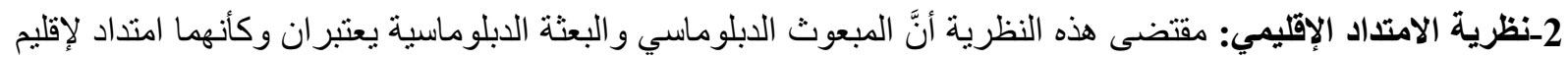

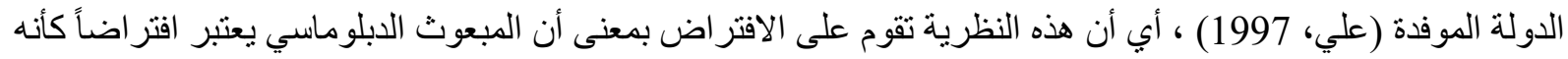

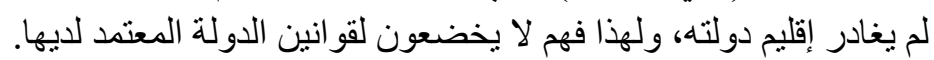

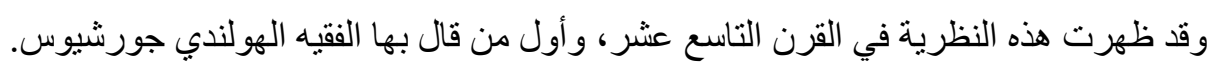

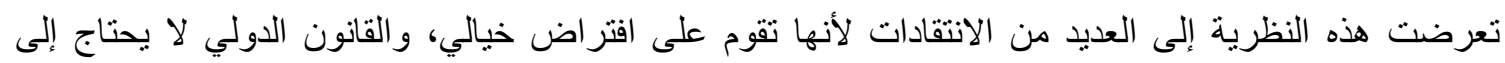

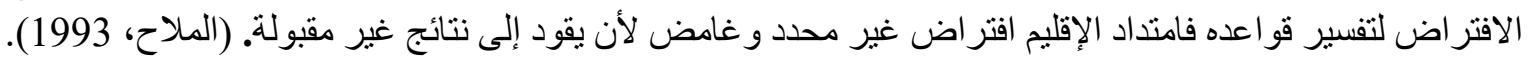

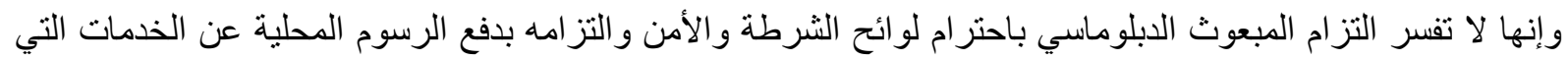
تقدم له (الأحمر ، 2009).

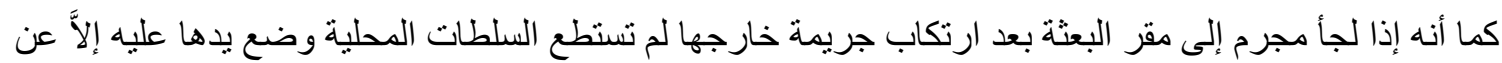

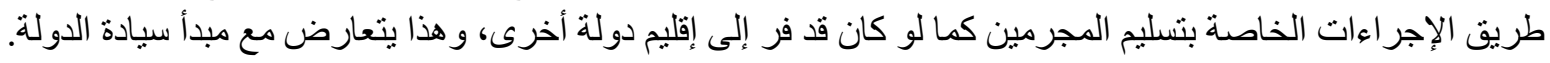

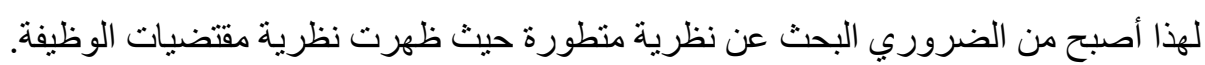

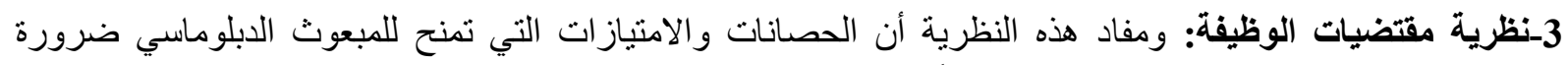

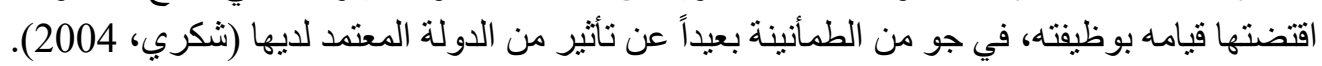

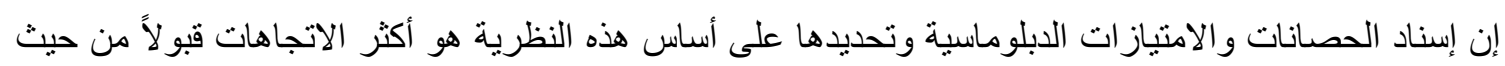

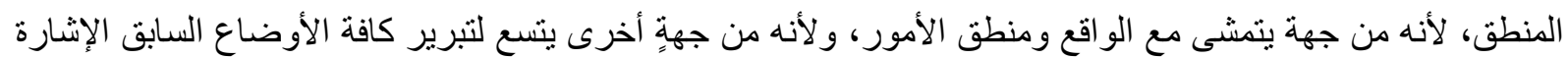

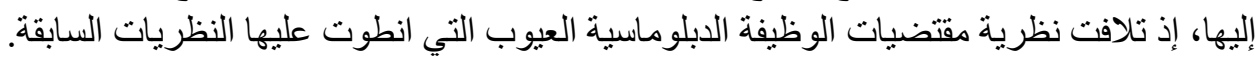

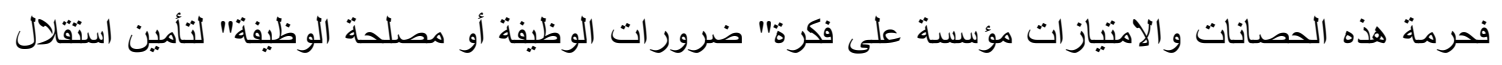

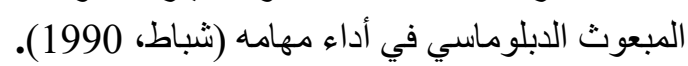

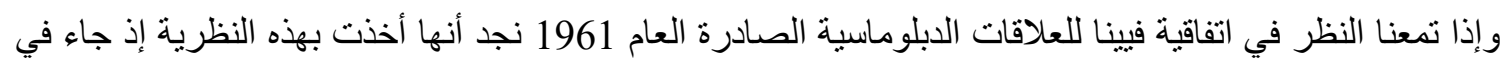

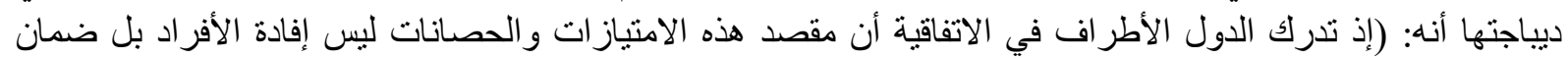
الأداء الفعَّال لوظائف البعثات الدبلوماسية). 
ثانياً: الأساس القانوني للحصانات والامتيازات الابلوماسية:

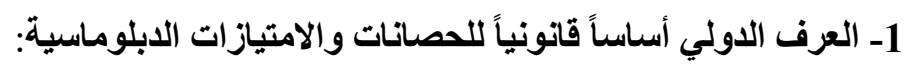

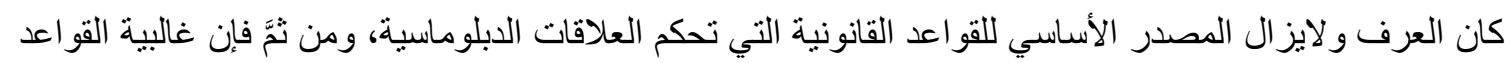

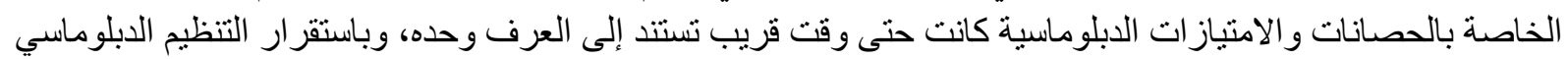

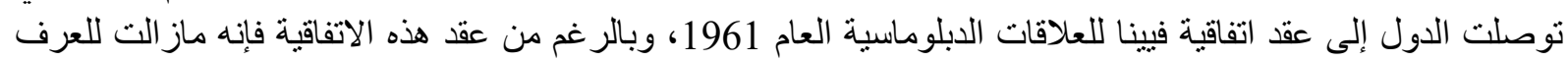

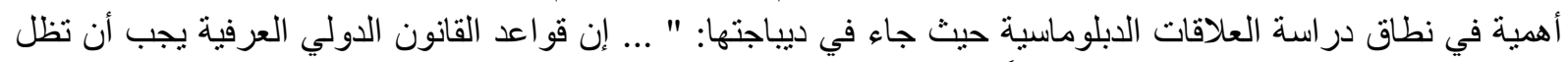
سارية بالنسبة للمسائل الني لم تعالج صر احةً في أحكام هذه الاتفاقية".

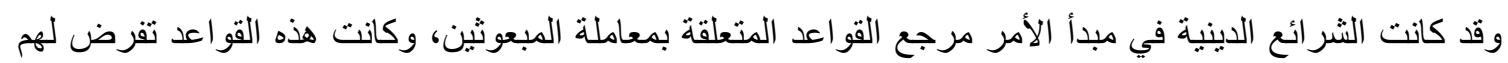

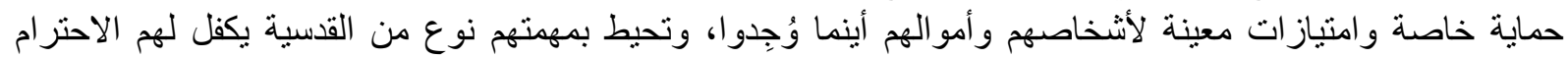

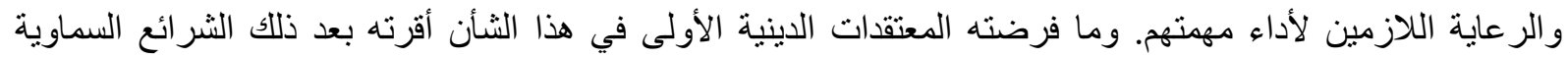

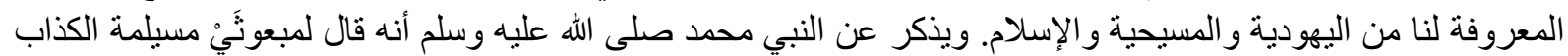

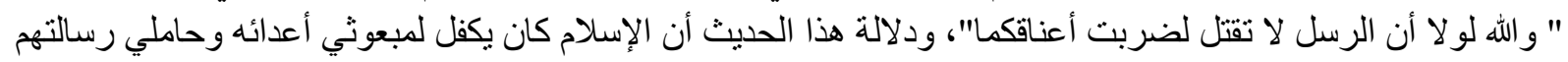

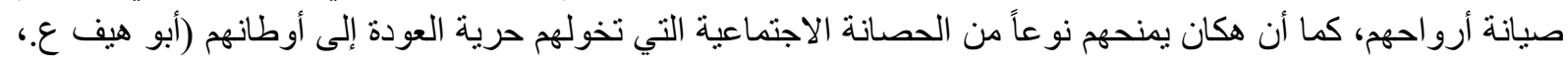

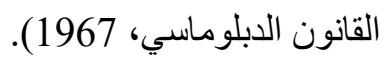

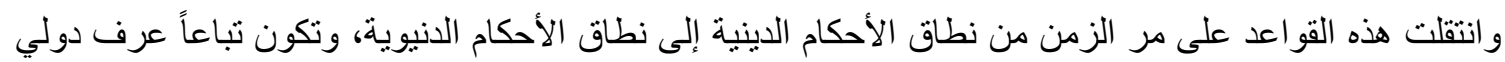

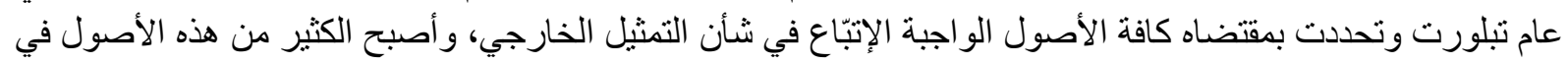

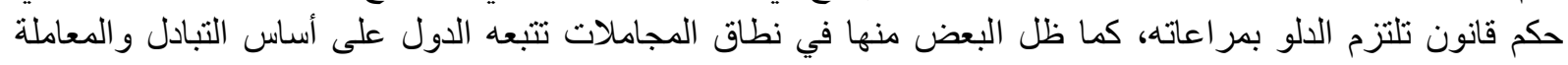
بالمثل.

2- المعاهدات الاولية والتشريعات الوطنية:

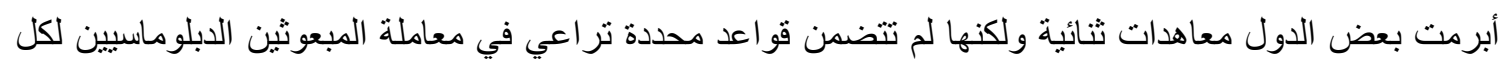

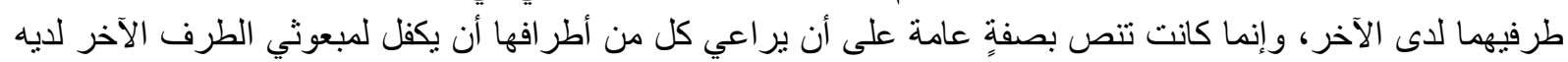

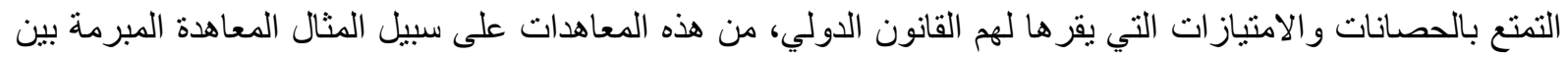

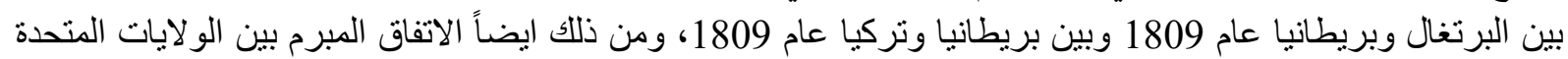

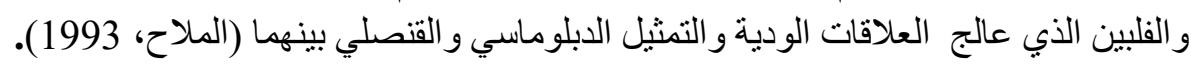

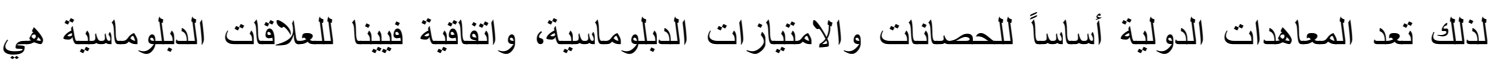

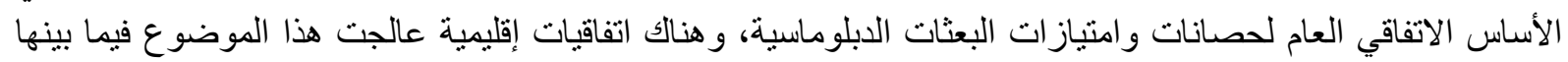
اتفاقية هافانا الموقعة بين الدول الأمريكية في 20 فبراير 1928 في مدينة هافانا بدولة كوبا خلال العانية العقاد المؤتمر الأمريكي السادس.

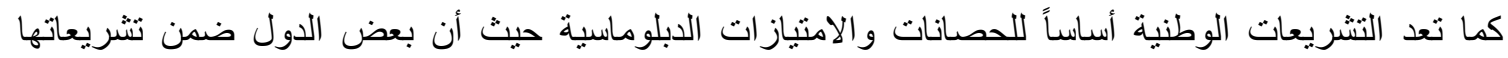

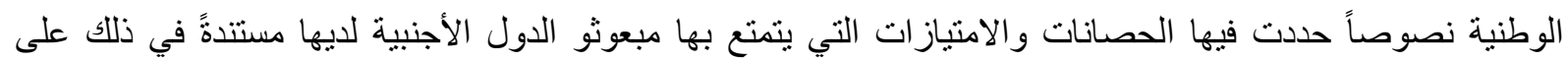

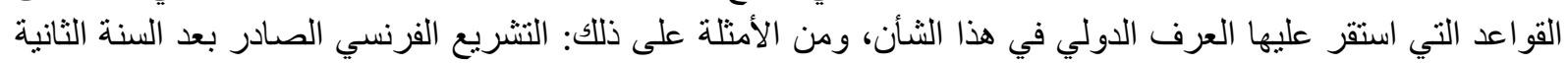

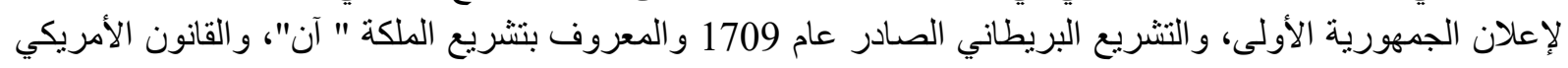

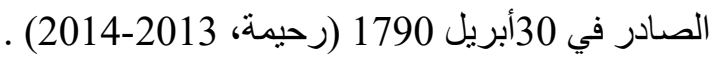


المبحث الثالث: أنواع حصانات وامتيازات المبعوث الدبلوماسي:

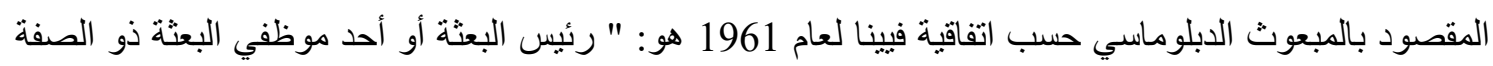

الدبلوماسية سواءً كان وزير مفوض أو مسنتشار أو سكرتير أو ملحق...." (إتفاقية فيينا، 1961 1961).

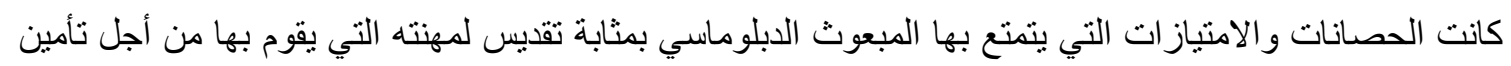

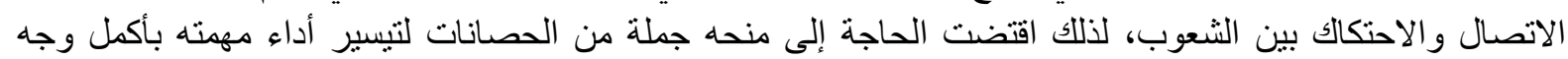

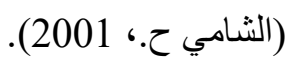

كما يكفل القانون الدولي المعاصر وغيرهم من أعضاء البعثات الدبلوماسية في حدود معينة حصانات وامتيازات

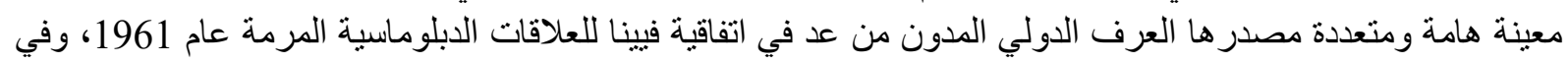

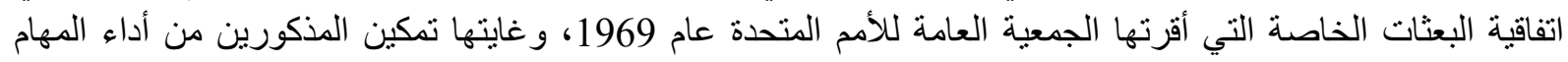

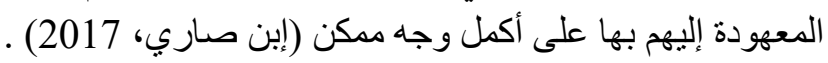
وبحسب اتفاقية فيينا للعلاقات الدبلوماسية لسنة 1961، فإن الحصانات و الامتياز ات الدبلوماسية منتوعة ومتعددة هي على ) ولى النحو التالي:

1- الحصانات و الامتياز ات الخاصة بمقر البعثة الدبلوماسية.

2-الحصانات و الامنياز ات أو التسهيلات المقررة لعمل البعثة الدبلوماسية.

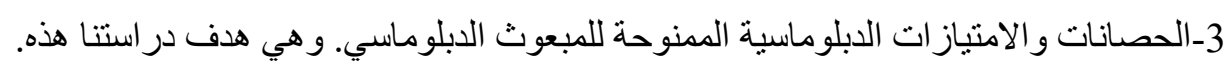

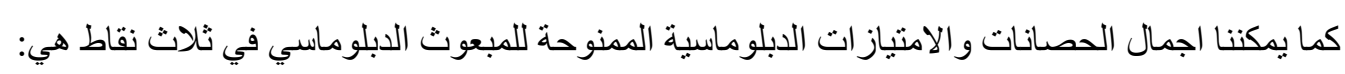
أولاً: الحرمة الثخصية (الحصانة الشخصية).

ثثانياً: الحرمة القضائية (الحصانة القضائية).

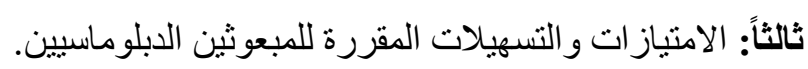

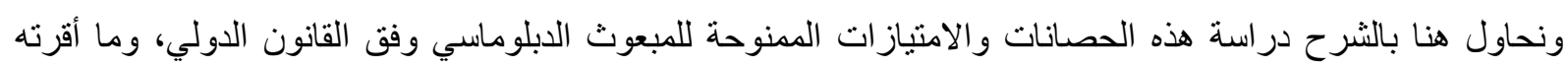
اتفاقية فيينا للعلاقات الدبلوماسية الصادرة عام لهام 1961.

أولاً: الحرمة الثخصية (الحصانة الثخصية):

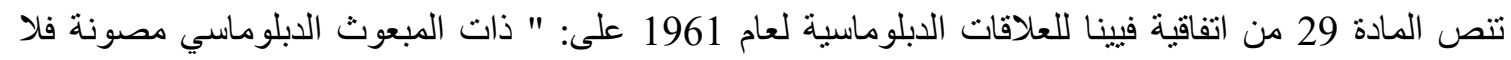

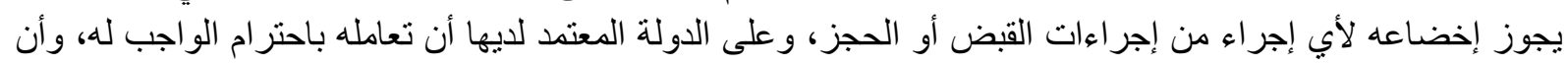

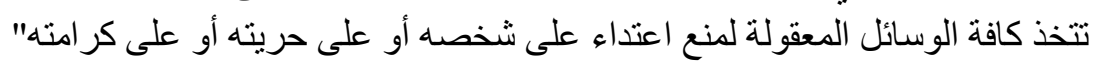

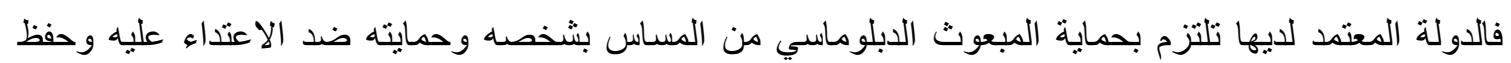

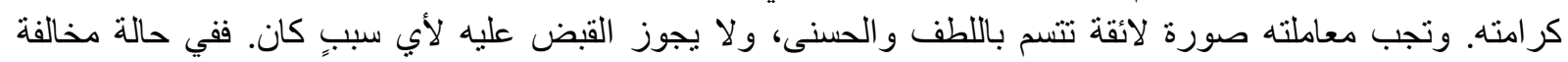

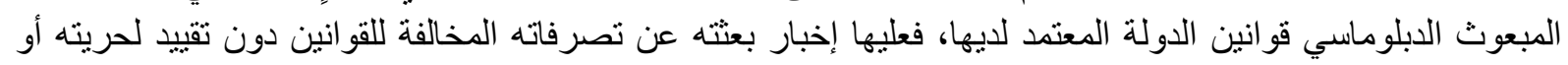
منعه من أداء عمله.

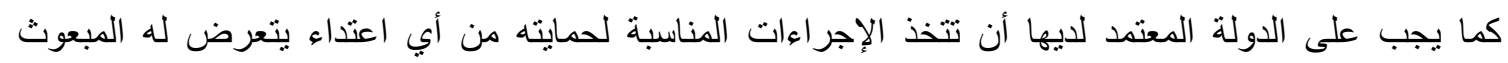

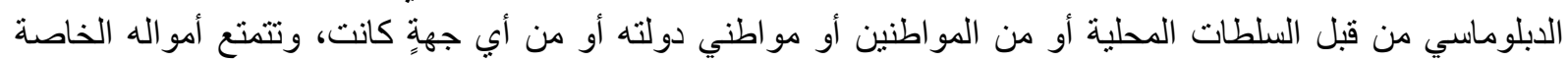

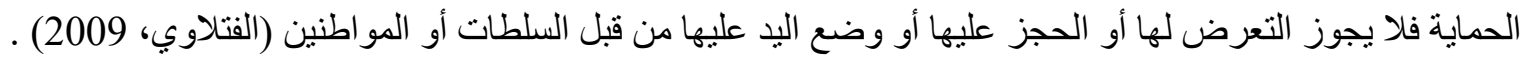

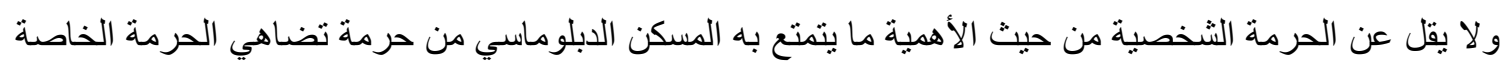

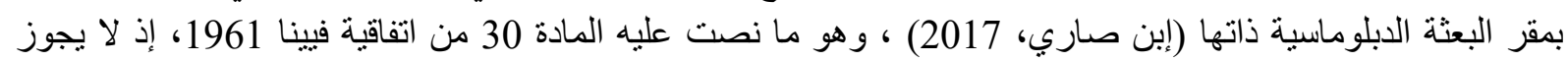

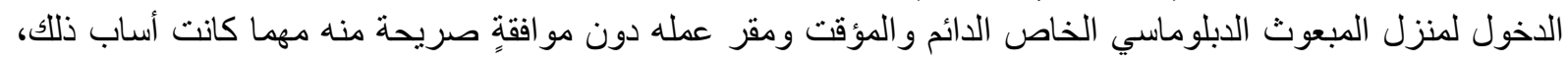

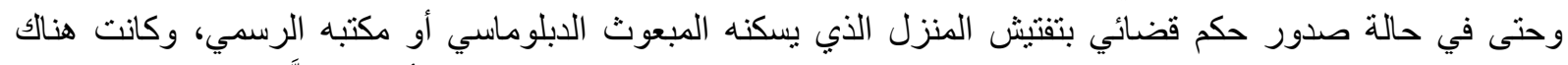

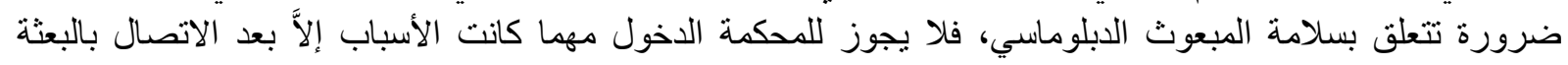

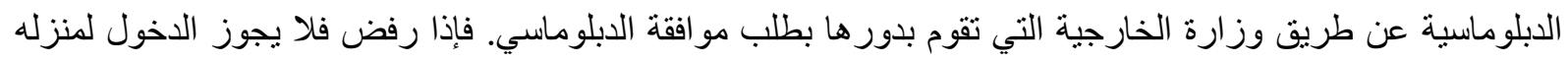




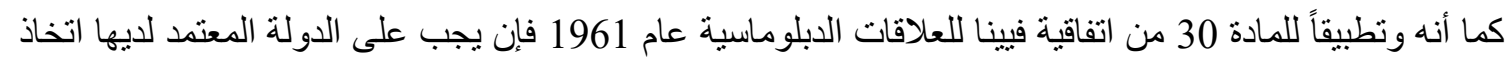

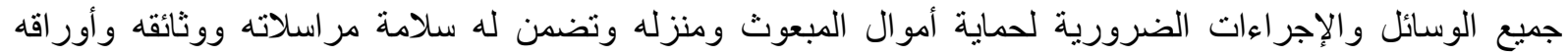

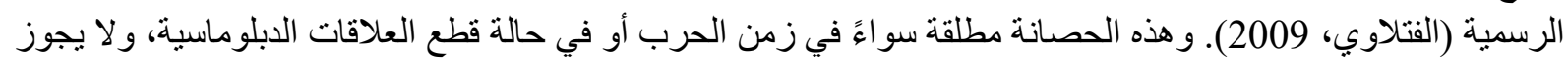

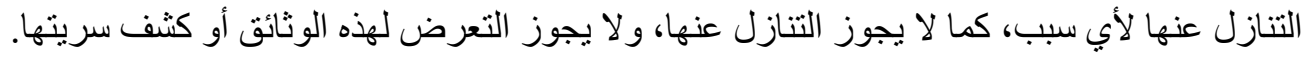

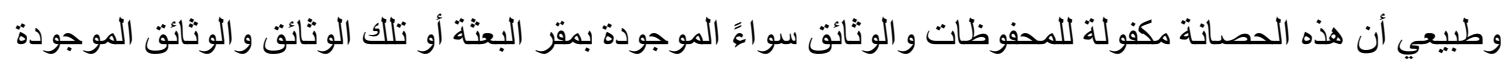

خارج المقر ومحفوظاتها (العناني، 1998).

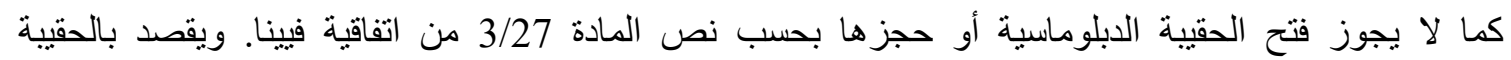
الدبلوماسية تلك الطرود التي تحتوي على المر اسلات الرسمية وكذلك الوثائق و الأشياء الموجهة حصر التهاً للاستعمال الرسمي.

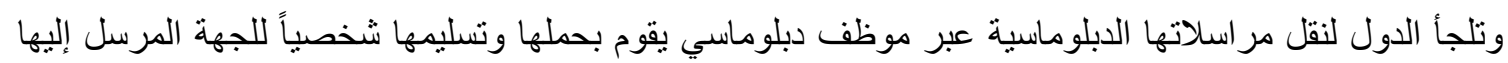

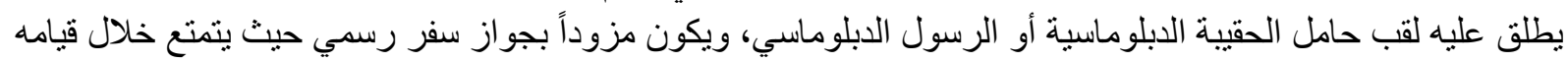

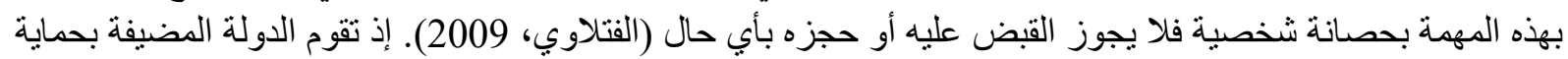

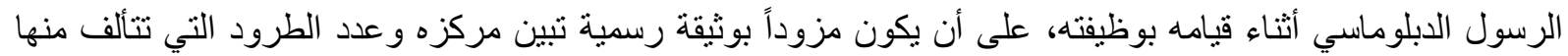

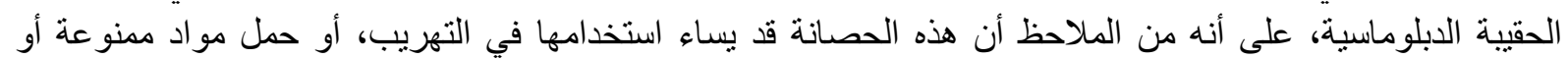

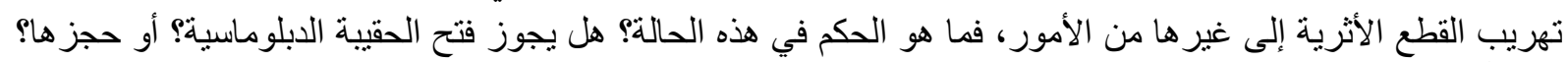

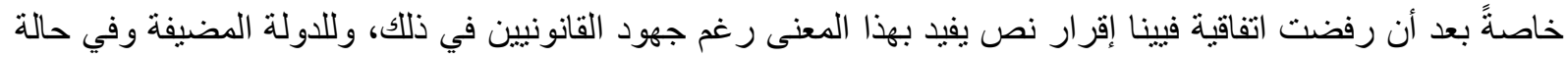

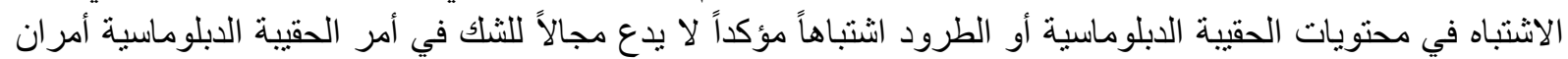

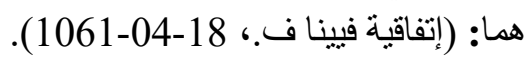

1- إما منع دخول الحقيبة أصلاً. 2-أو فتحها بعد استئذان وزارة الخارجية، وفي حضور رئيس البعثة الدبلوماسية.

ثانياً: الحرمة القضائية (الحصانة القضائية):

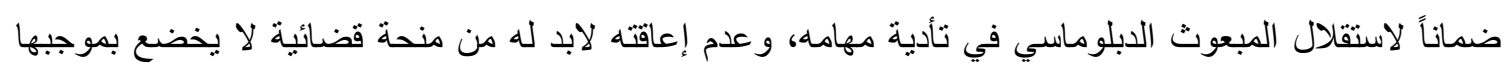

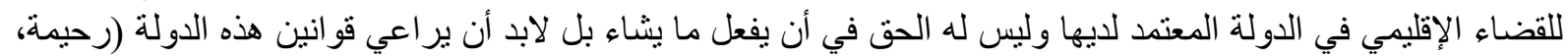

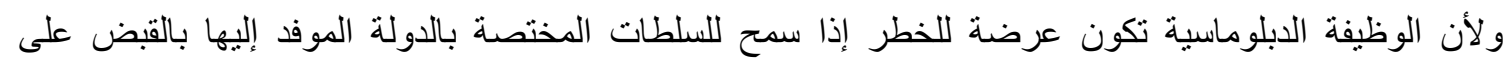

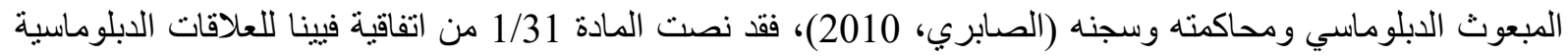

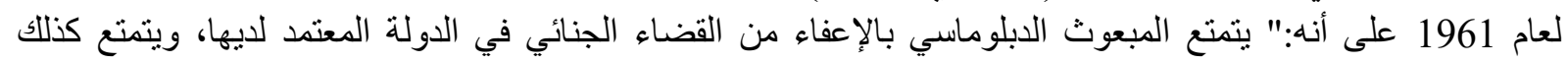
بالإعفاء من القضاء المدني و الإداري".

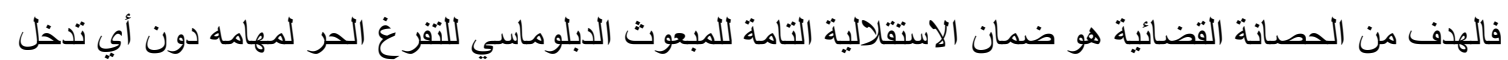

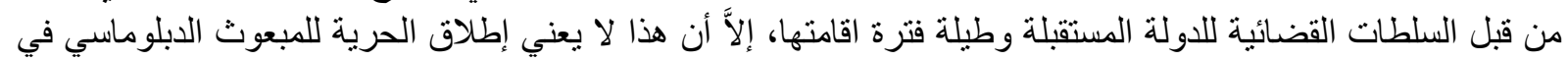

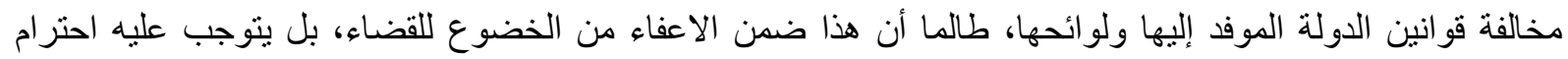

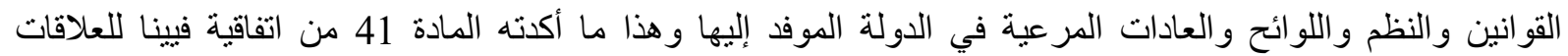

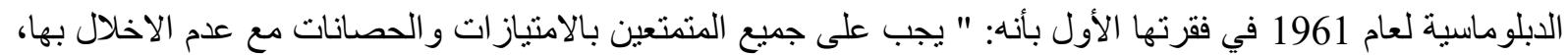

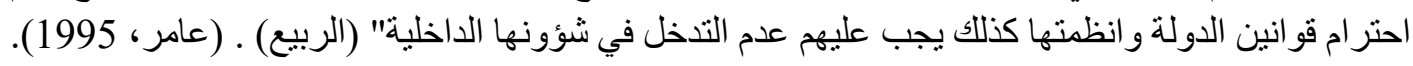
و هذا يدل على أن الحصانة القضائية ليست حصانة مطلقة و إنما هي إعفاء مؤقت من القضاء الإقليمي للادولة المعتمد لديها.

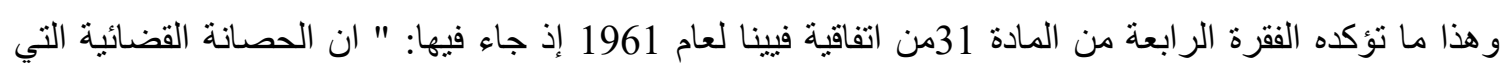

يتمتع بها المبعوث الدبلوماسي في الدولة الموفد إليها لا تعفيه من الخضوع لقون لقضاء الدولة المناء الموفدة (المعتمدة) " (ولي). وفي سبيل دراسة الحصانة القضائية للمبعوث الدبلوماسي وما تثيره من إثكاليات تتعلق بأمن الدولة المعتمد لديها فإنه لابد الداء

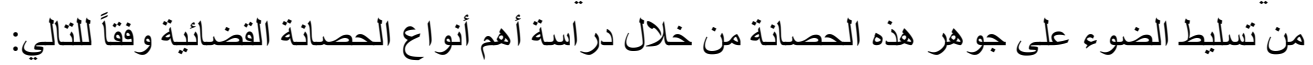

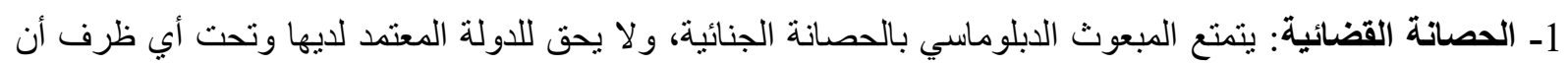
تحاكمه أو تعاقبه بو اسطة محاكمها الجنائية، وهي حصانة مطلقة حيث نصت الفقرة الأولى من المادة 31 من اتفاقية فيبنا 
للعلاقات الدبلوماسية لعام 1961 على: " يتمتع المبعوث الدبلوماسي بالإعفاء من القضاء الجنائي في الدولة المعتمد لديها،

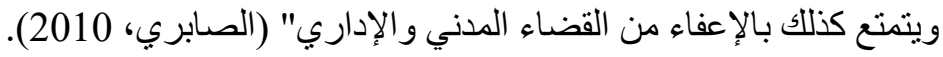

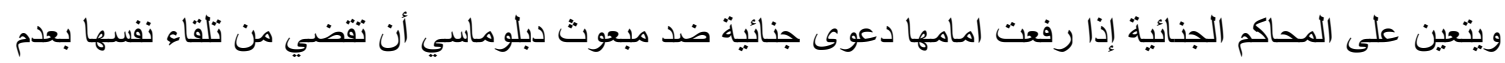

الاختصاص (عامر، 1995).

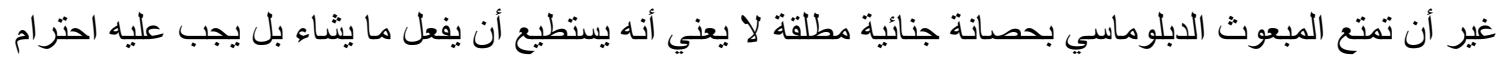

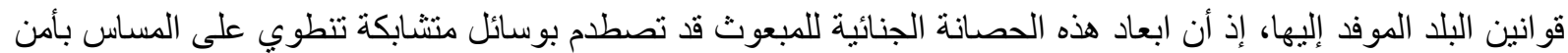

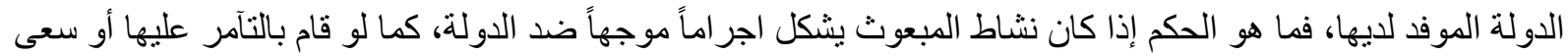

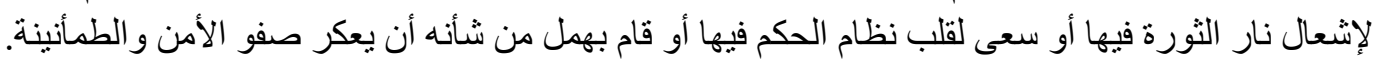

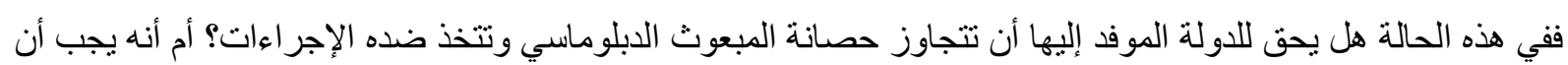

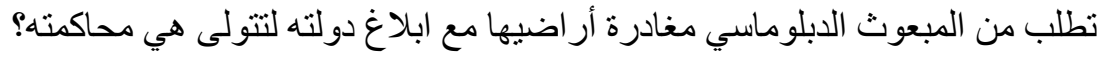

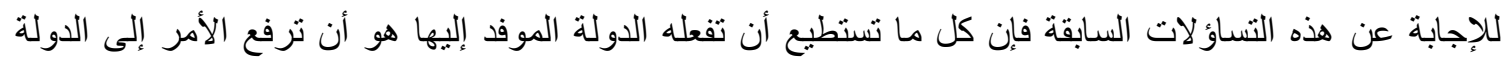

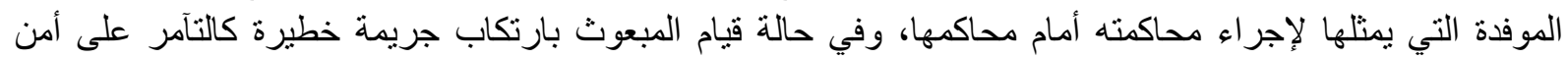

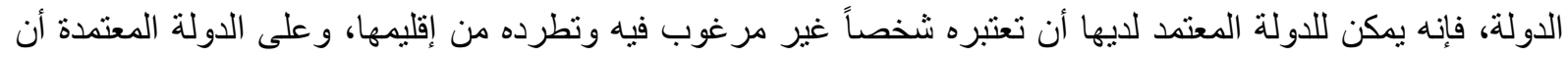

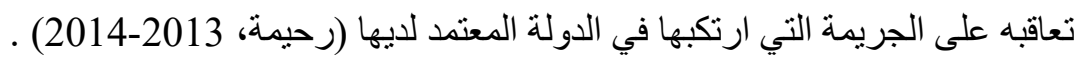
2- الحصانة المدنية والإدارية: بيتند عدم خضوع المبعوث الدبلوماسي لقضاء الدولة الموفد إليها في المسائل المدينة إلى إلى اعتبارين:

ـالاعتبار الأول: إن إقامة المبعوث مهما طال أمدها فهي إقامة عارضة تفرضئ إنها عليه مهام وظيفته، فضلاً عن أن مقر البعثة

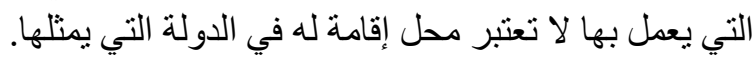

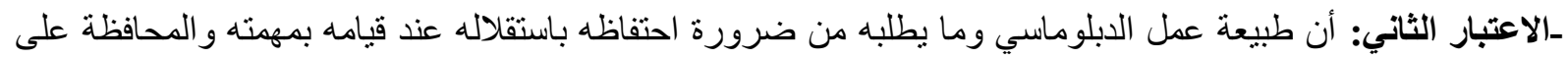

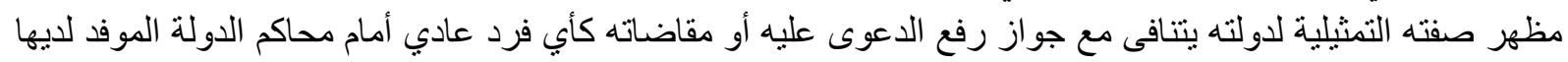
(الصابري، 2010).

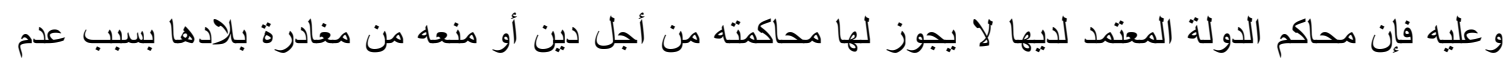

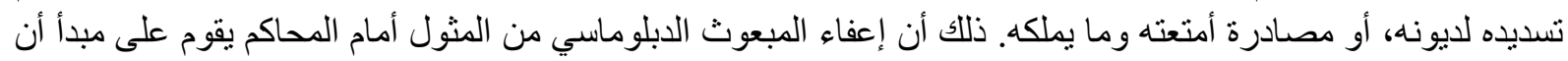

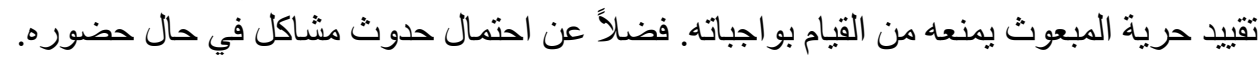

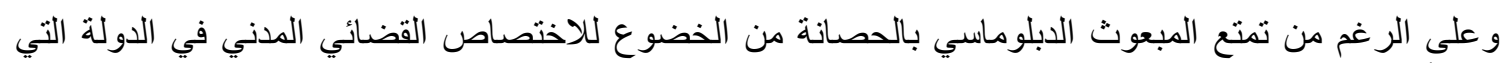

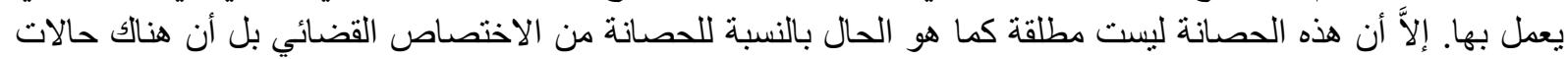
يخضع فيها المبعوث الدبلوماسي للاختصاص القضائي المدني في الدولة المعتمد لايها (رحيمة، 2013-2014).

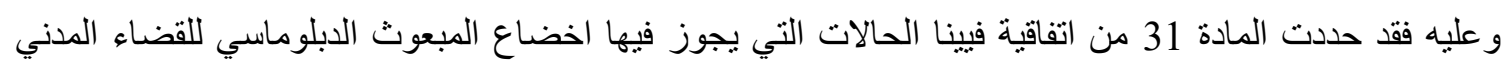
والإداري للادولة الموفد إليها و التي تتمثل في التالي:

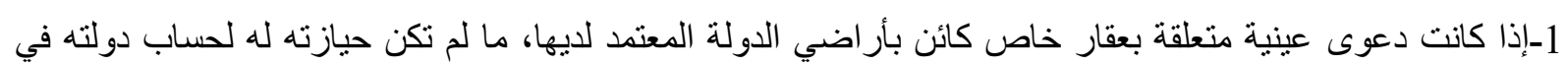
خصوص أعمال البعثة.

2-إذا كانت دعوى خاصة بمير اث (تركة)، يكون المبعوث الدبلوماسي قد عُعِّنَ منفذاً للوصية أو مديراً للتركة أو وارثاً

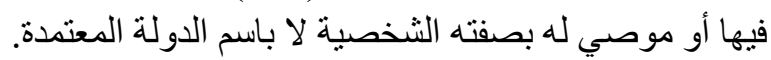

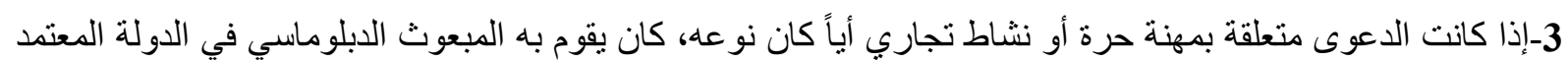

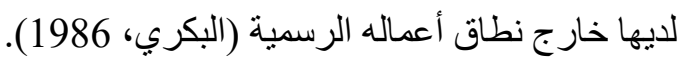

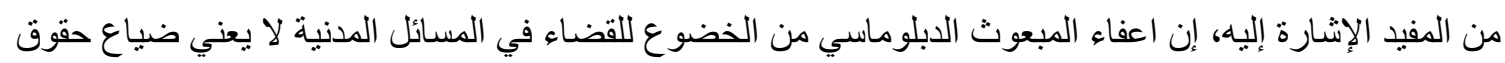

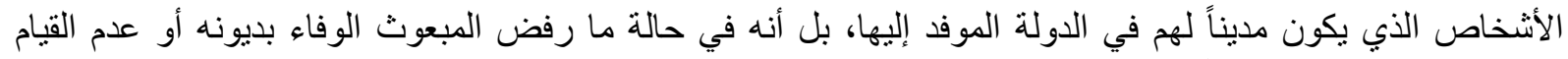

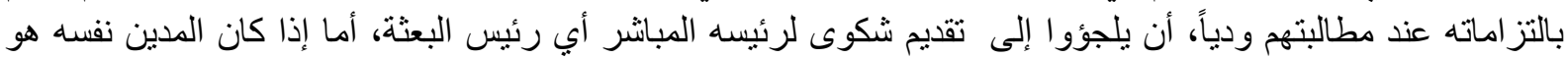

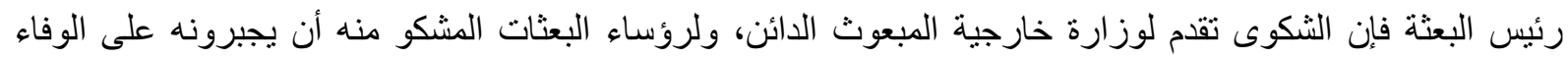

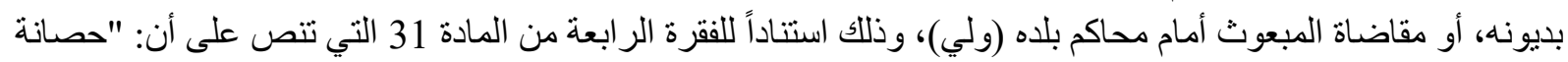

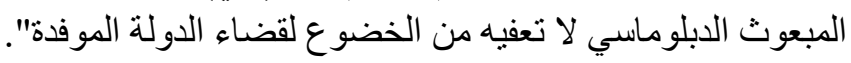


كما يمكن أن تحل هذه الإشكالية ودياً وذلك بأن يقوم وزير الخارجية الدولة الموفد إليها باستدعاء رئيس بعثة العضو

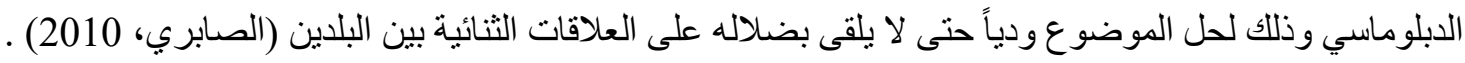

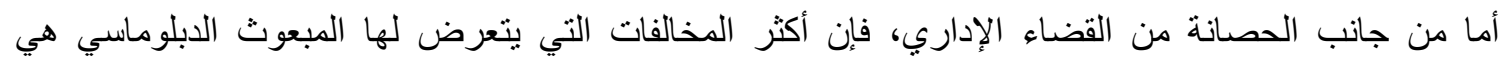

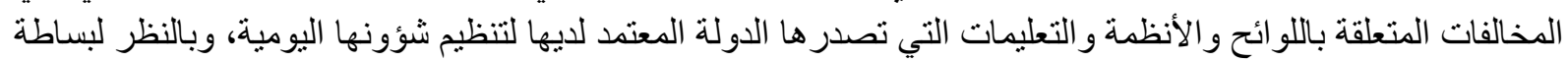

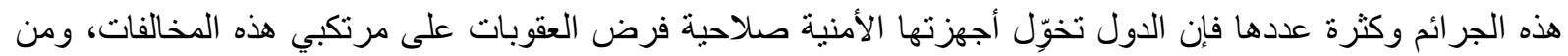

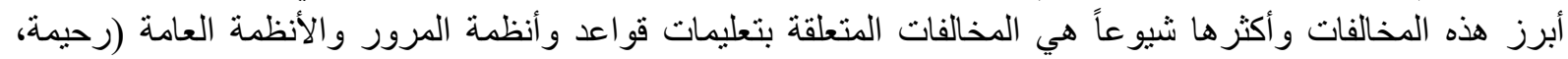

.2014-2013

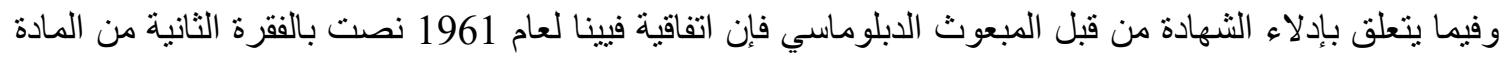

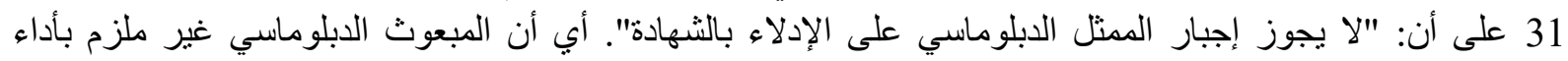

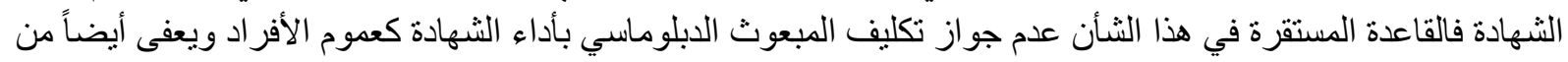

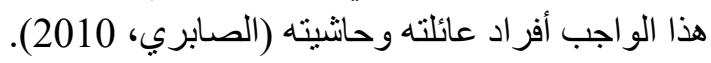
أما إذا كان لا بد من الاستماع إلى المبعوث الدبلوماسي، فإنه يمكن أن يطلب إليه ذللك بالطرق الدبلوماسية أي عن

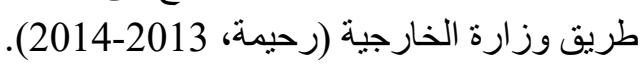

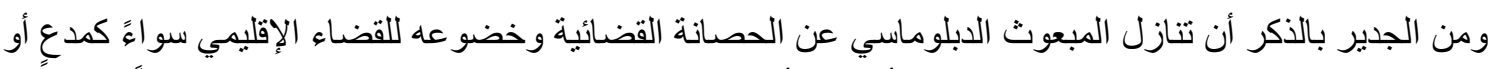

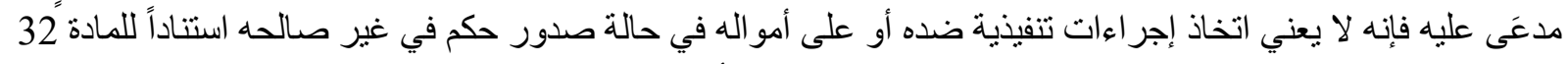

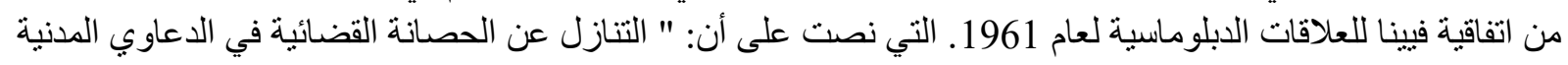

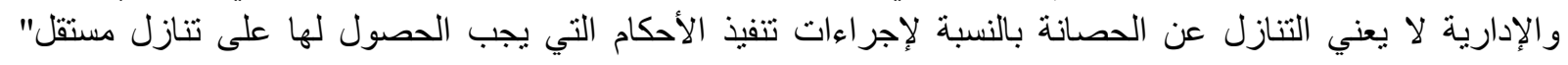

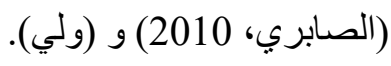

\section{ثالثثاً: الامثيازات المالية والتسهيلات الأخرى المقررة للمبعوثين الابلوماسيين:}

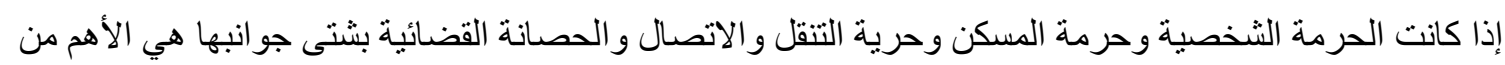

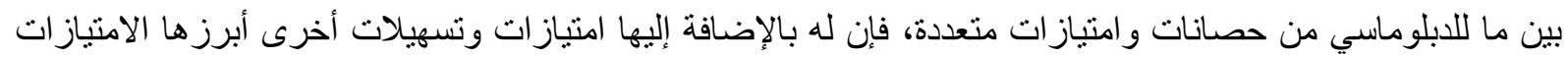

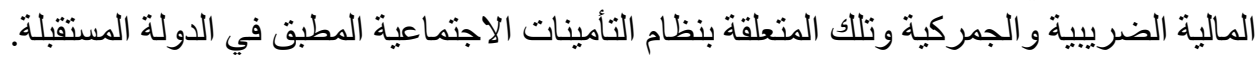
كما أصبحت هذه الإعفاءات جزءاً من العمل الدبلوماسي لا يستطيع المبعوث الدبلوماسي أن يعمل بشكل جيد بدونها (إين صاري، 2017) .

ويمكن الحديث عن فريق الامتباز ات المالية التي يتمتع بها المبعوث الدبلوماسي على النحو التالي:

أولاً: إعفاء المبعوث الدبلوماسي من الضرائب والرسوم الجمركية:

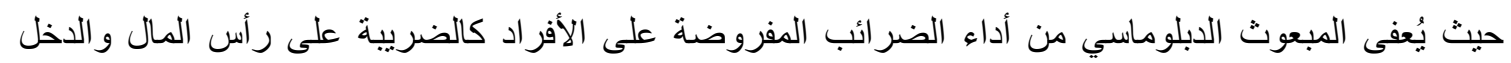

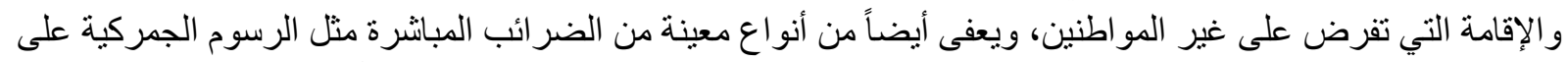

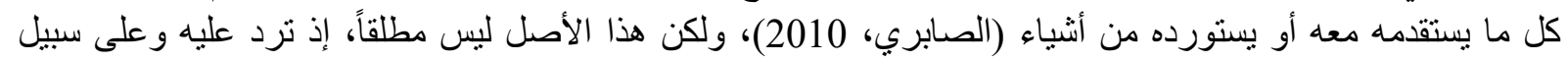

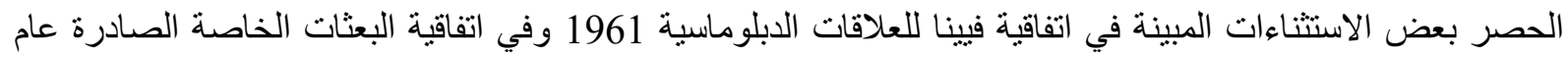

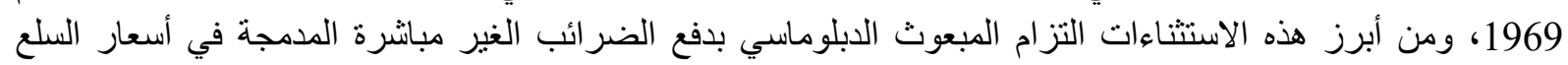

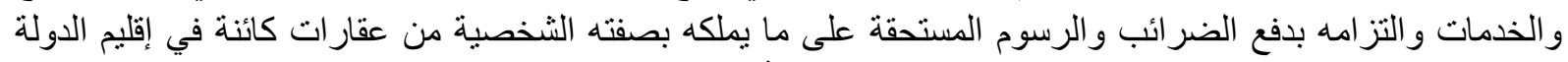

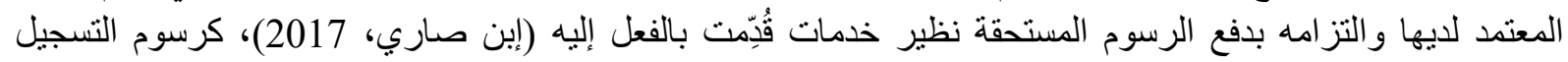

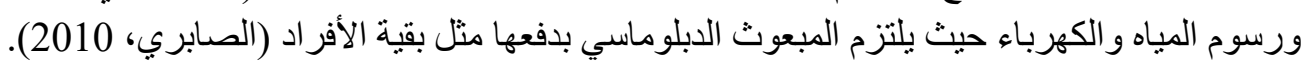

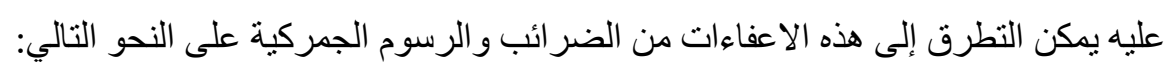

1- الإعفاءات من الضر ائب المباشرة:

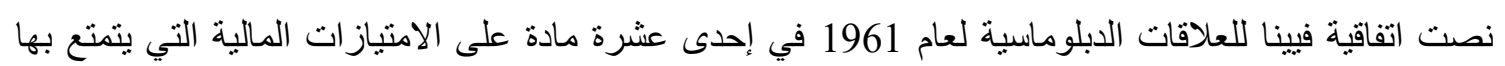

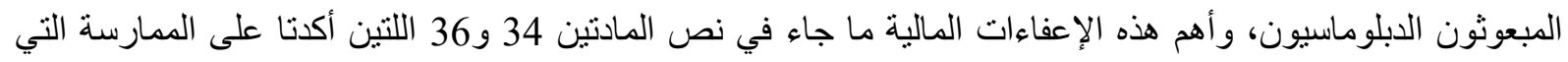

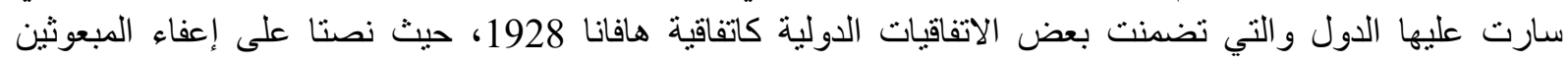

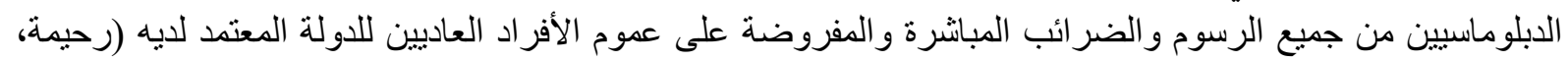


هذا على عكس الضرائب غير المباثرة والرسوم مقابل خدمات معينة التي لا يعفى منها المبعوثون الدبلوماسيون، بل

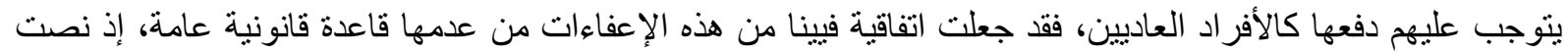

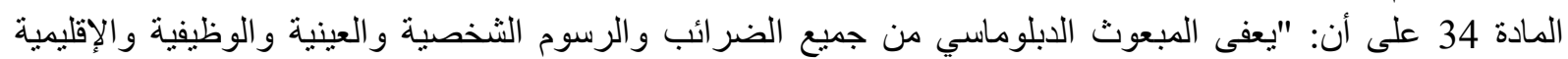

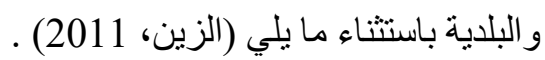
أ. الضر ائب غير المبانترة التي يشتمل عليها بشكل طبيعي سعر البضائع وائع والخدمات.

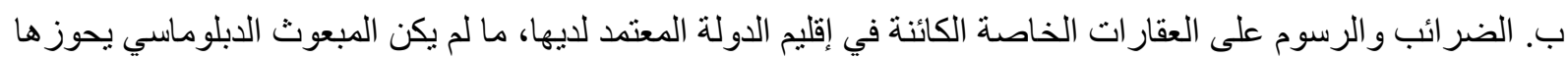
لحساب الدولة المعتمدة لاستخدامها في أغر اض البعار البثة.

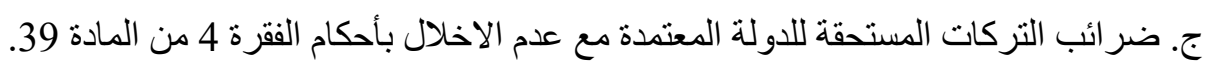

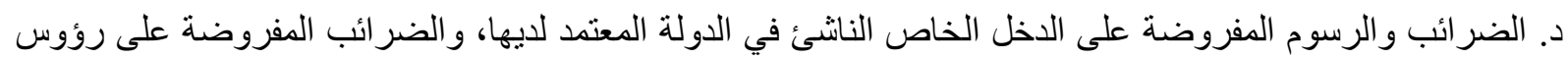

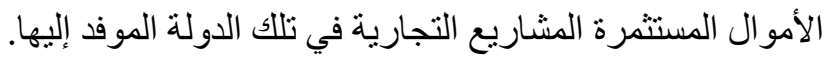

ه. الضر ائب و السوم المستوفاة مقابل خدمات معينة.

و. رسوم التسجيل و القيد و الرهن و الطابع المتعلقة بالأملاك العقارية، مع مر اعاة أحساة أحكام المادة 23.

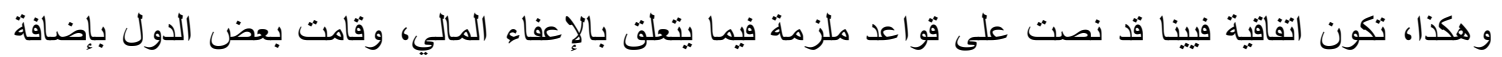

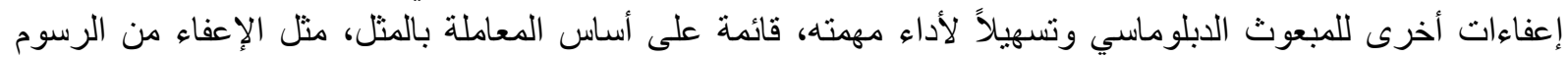

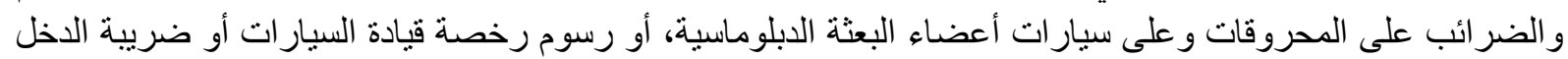

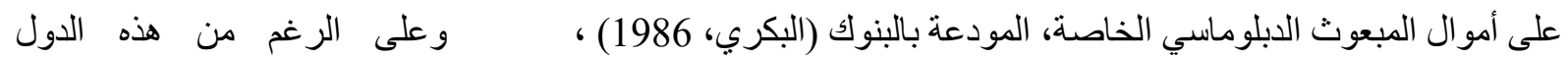

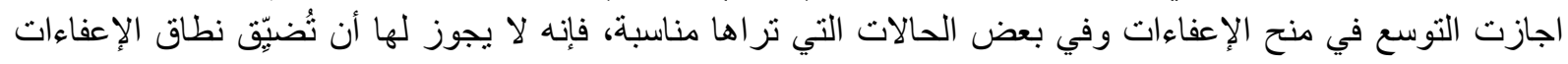

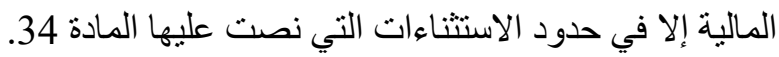

2- الإعفاء من الرسوم الجمركية:

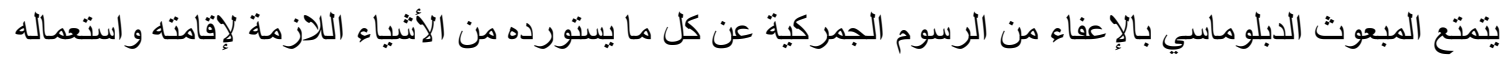

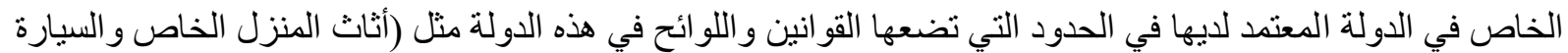

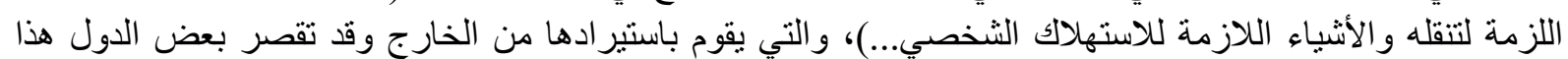

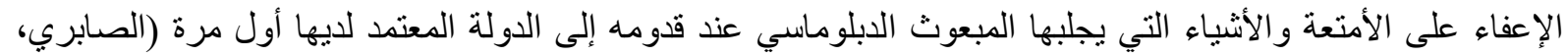

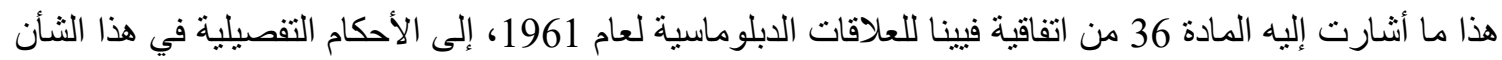

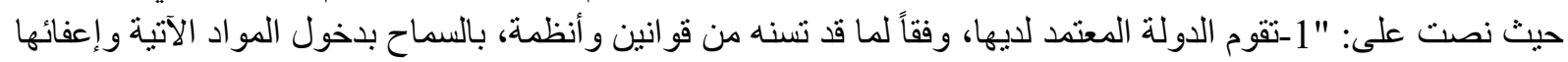

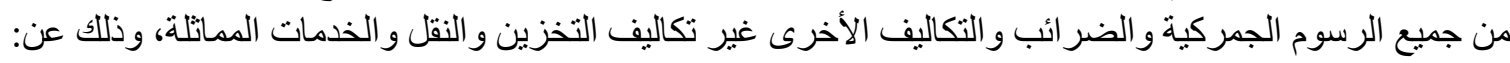
أـالأشياء المخصصة للاستعمال الرسمي للبعثة.

بـالأشياء المخصصة للاستعمال الثخصي للمبعوث الدبلوماسي و لأفراد أسرته الذين يقيمون معه في معيشة واحدة، بما في فيها المواد المعدة لإقامته.

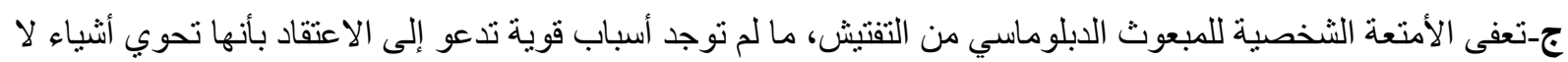

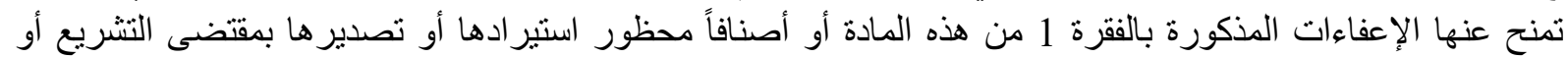

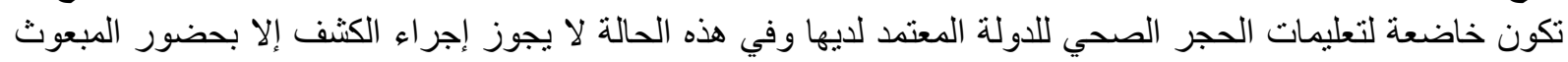
الدبلو ماسي أو ممثلك المفوض (رحيمة، 2013-2014).

وقد نصت الفقرة الأخيرة من المادة 36 من اتفاقية فيينا للعلاقات الدبلوماسية 1961، و اتفاقية فيينا للبعثات الخاصة

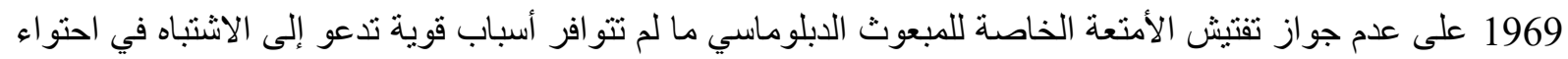

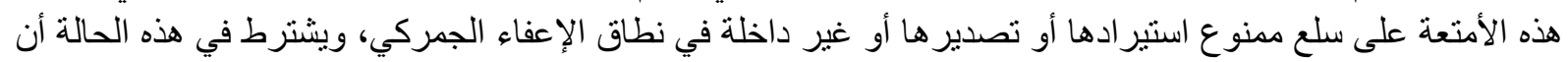

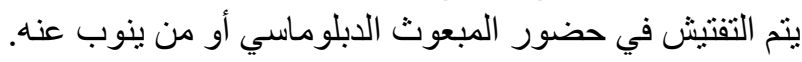

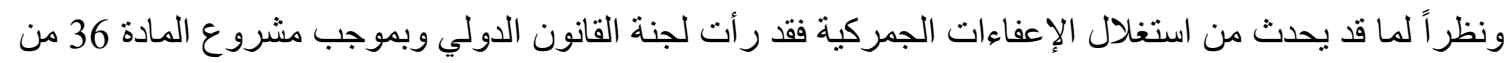
اتفاقية فيينا للعلاقات الدبلوماسية عام 1961 بأن تقر للاولة الحق في أن تفرض عن طريق التشريعات واللوائح الخاصنة 
القيود التي تراها مناسبة لدنع هذا الاستغلال كتحديد قدر السلع المستوردة التي تتمتع بالإعفاء و المدة التي يجب أن ينم

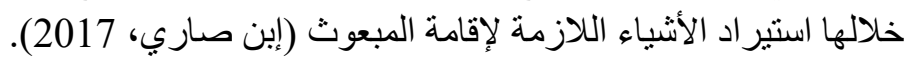

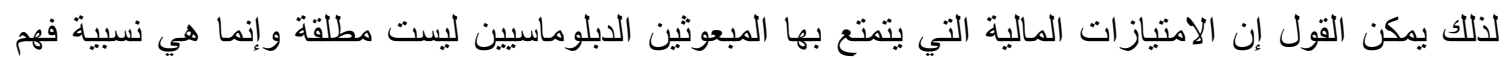

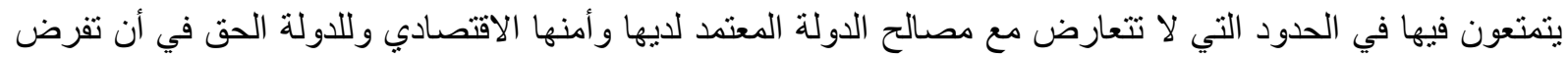
عن التشريعات و اللوائح القيود التي نر اها مناسبة لمنع إساءة استغلال الامنياز ات المالية للمبعوث الدبلوماسي (الصابري،

\section{ثثانياً: الامتيازات والتسهيلات الأخرى للمبعوث الابلوماسي:}

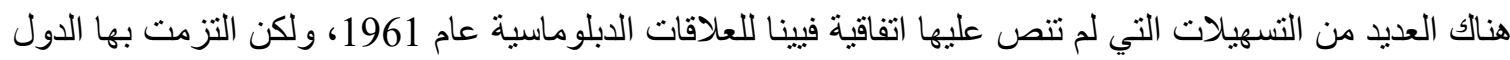
على أساس المعاملة بالمثل، ومن أهم هذه التسهيلات ما لفيلي: 1-إعفاء المبعوث الدبلوماسي و أفر اد أسرته من تطبيق الإجر اءات المات المتعلقة بالإقامة:

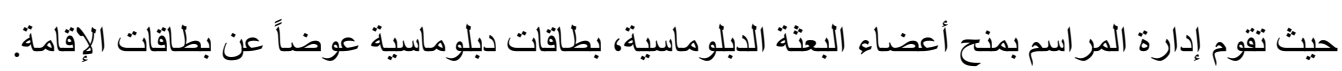

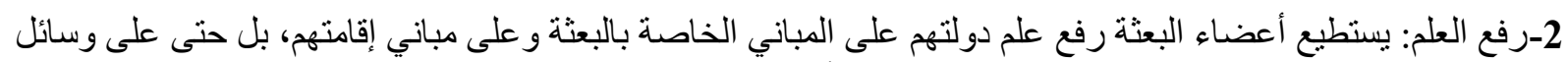

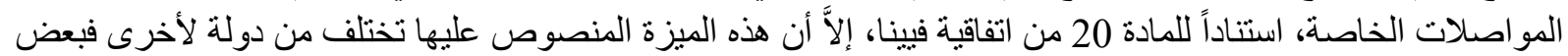

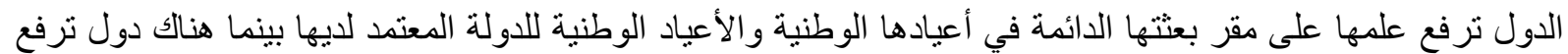

العلم يومياً فوق مقار بعثاتها.

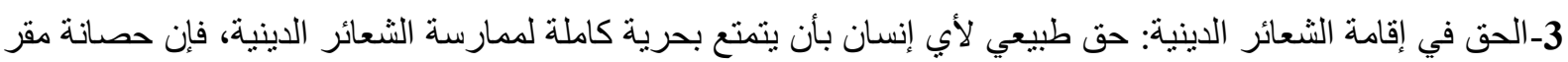

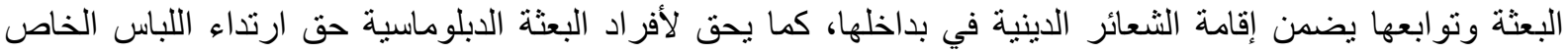

لدولتهم الموفدة بالدولة الموفد إليها.

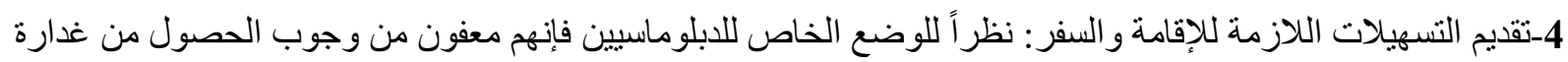

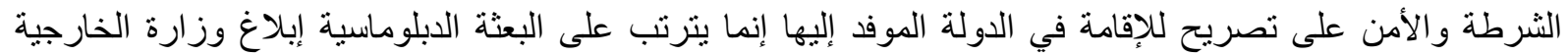

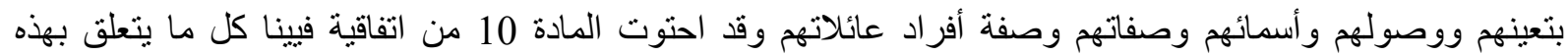

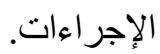

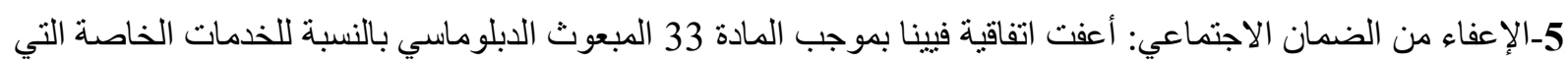

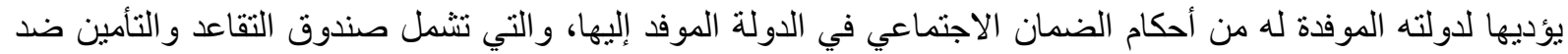

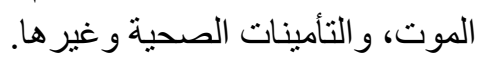

و على الر غم من ذلك تمنح الاتفاقية المبعوث الدبلوماسي حق الاستفادة من الأنظمة و الخدمات وبشكل اختباري وذلكاتك بعد تأمين مو افقة الدولة الموفد إليها ـالمعتمد لديها_على ذلك.

ويبدأ تمتع المبعوث الدبلوماسي بالحصانات والامتيازات المقررة لهاته في الدولة المعتمد لديها بمجرد دخوله إقليمها

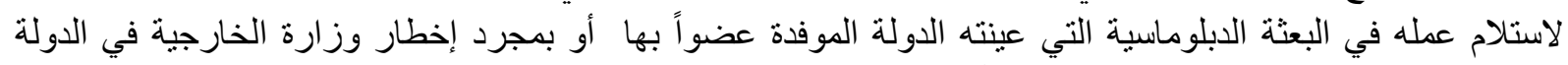
المستقبلة (الموفد إليها) بتعيينه إذا كان موجوداً بالفعل في إقليم هذه الدولة وقت صدور قرابة التار التعيين (إين صاري، 2017)،

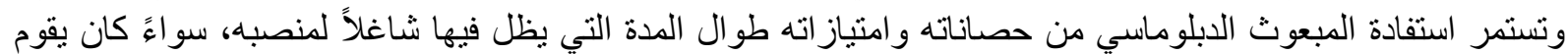

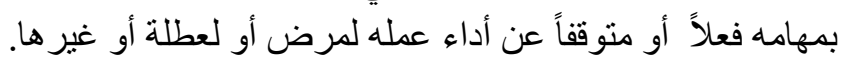

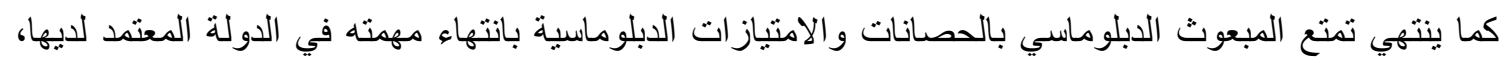

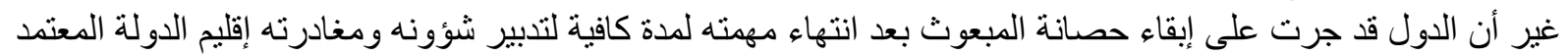

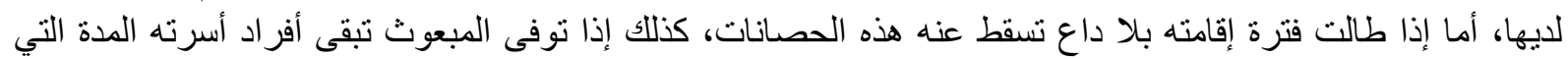

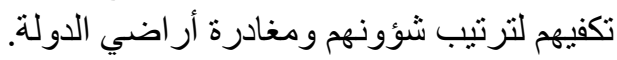

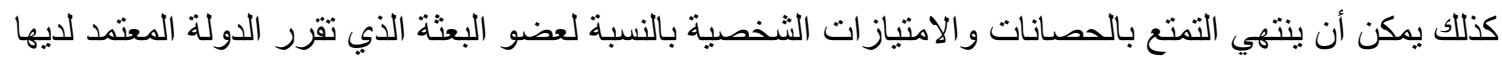

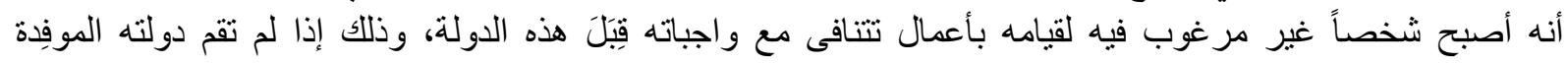

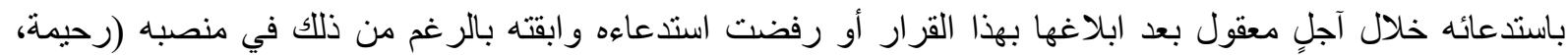


2014-2013)، كما قد تنتهي مهمة المبعوث الدبلوماسي بفقد الدولة التي يمثلها المبعوث حق التثثيل الخارجي نتيجة

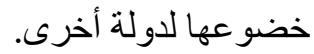
وقد حددت المادة 39 من اتفاقية فيينا للعلاقات الدبلوماسية عام 1961 بداية وانتهاء تمتع المبعوث الدبلوماسي بالحصانات و الامتياز ات الدبلوماسية سالفة الذكر.

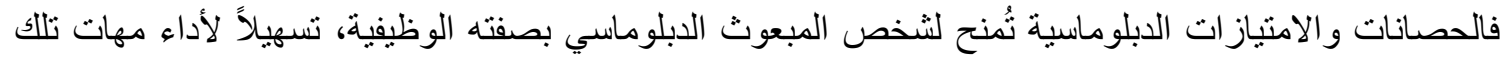

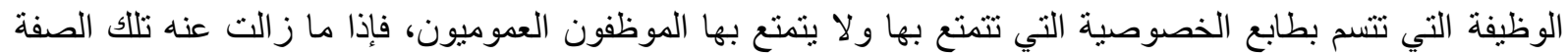
(الدبلوماسي) بفقدانه لوظيفته الدبلوماسية سواء باستقالته أو بإحالته على التقاعد أو لأي سبب نم ذكر التها آنفاً، لم يعد يتمتع باستمر ار تللك الحصانات و الامتياز لوات (الزين، 2011).

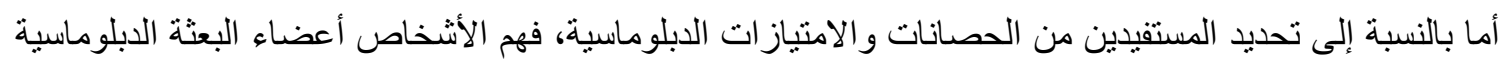

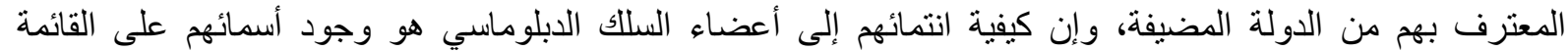
الدبلوماسية.

ويتحدد عدد أعضاء البعثة الدبلوماسية باتفاق بين الدولة المعتمدة والدولة المعتمد لايها، وتشمل البعثة الدبلوماسية الفئات التالية: 1-رئيس البعثة: و هو الثخص الذي يتولى تمثيل دولته في الخارج بصفة دائمة في كل ما يمس علاقاتها الدولية مع الدول

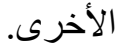

2-أعضاء البعثة: و هم الموظفون الذين تعينهم الدولة الموفدة للبعثة للعمل مع رئيس البعثة وهم ثلاث فئات هي كالآتي: أ. الموظفون الدبلوماسيون: و هم الذين يشغلون درجات دبلوماسية، ويشمل هؤلاء المستشارين، و السكرتيرين والملحقين،

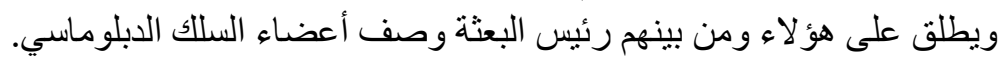
ب. الموظفون الإداريون و الفنيون: وهم من يقومون بالأعمال الإدارية الفنية.

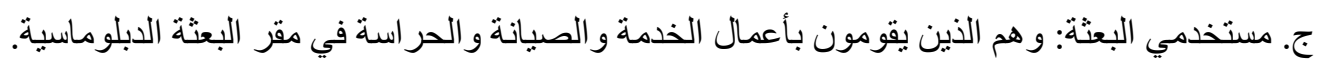
3-الخدم الخصوصيين: وهم الذين بعملون في الخدمة المنزلية لرئيس البعثة أو لأحد أعضائها.

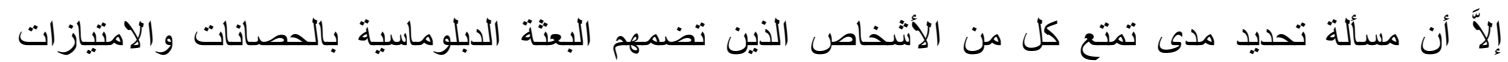

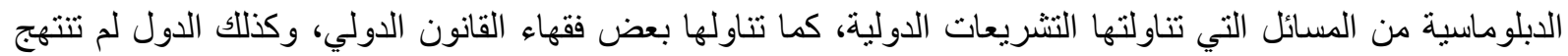

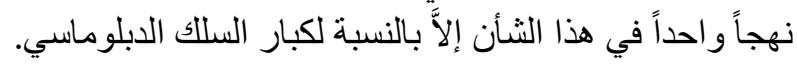
كما أن الدول لم تذهب مذهباً واحداً بالنسبة لمدى الحصانات و الامتياز ات التئي التي تمنح للمبعوث الدبلوماسي الذي يكون

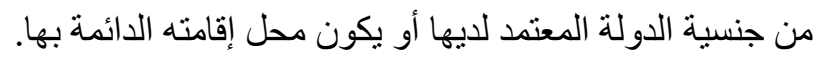

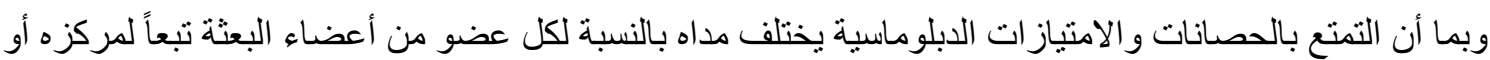

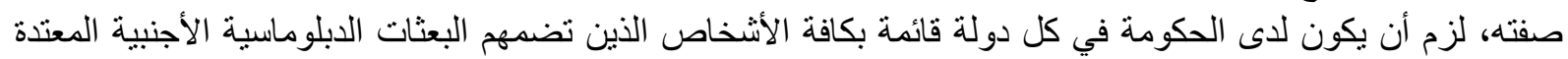

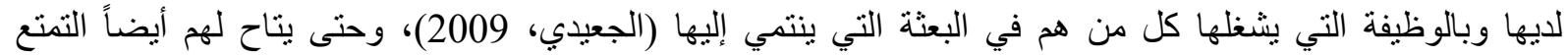

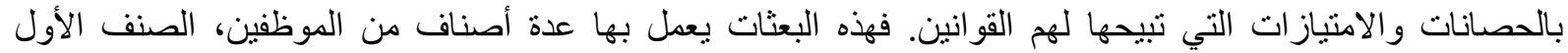

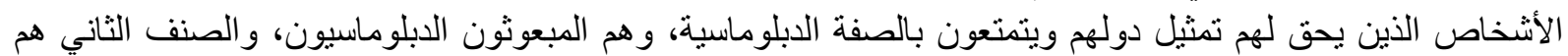
الأشخاص الذين يقومون بالأعمال الإدارية والفنية وهم الاداريون و الفنيون والمستخدمون، أما الصنف الثالث فهم الخدم الخاصون لدى المبعوث الدبلوماسي (ولي).

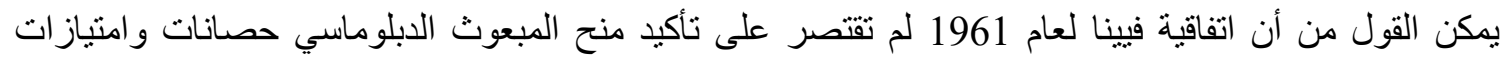

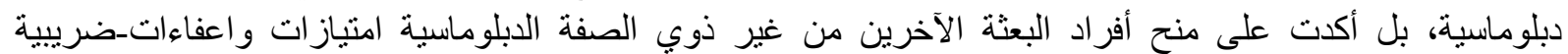

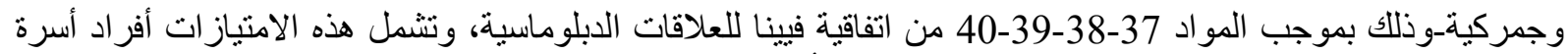

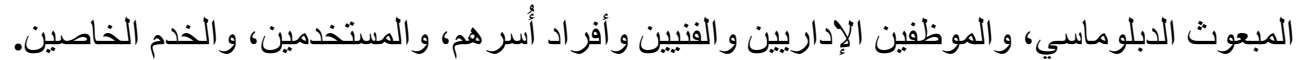

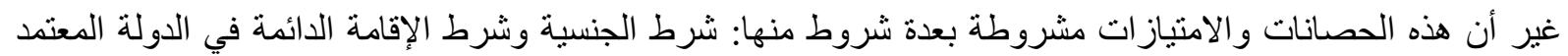
لديها، وشرط المعيشة تحت سقفٍ واحد (رحيمة، 2013-2014). 
فقد حددت المادة 37 من اتفاقية فيينا للعلاقات الدبلوماسية لعام 1961 فئات هؤلاء الأشخاص كما تحدد شروط

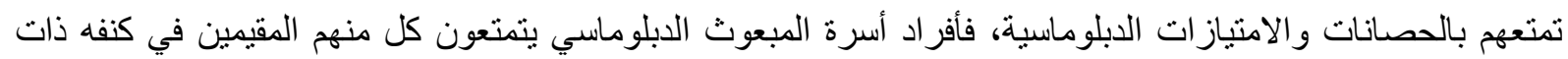

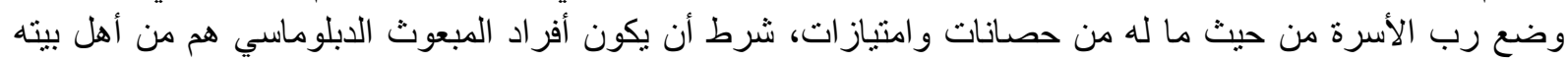

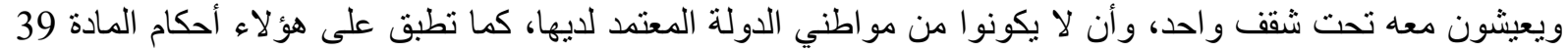

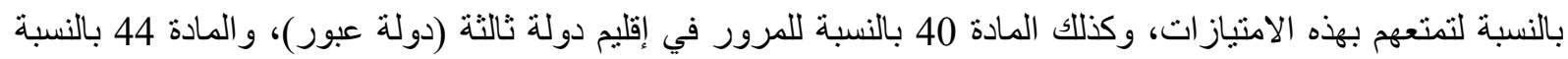

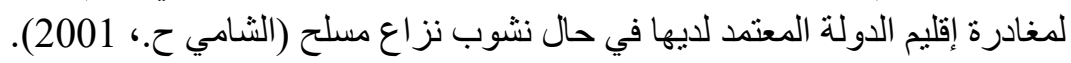

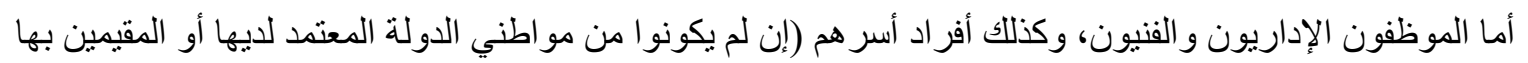

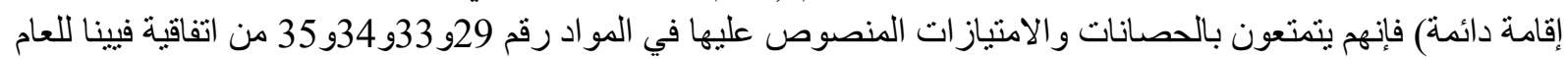

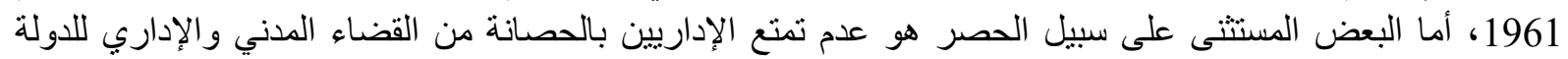

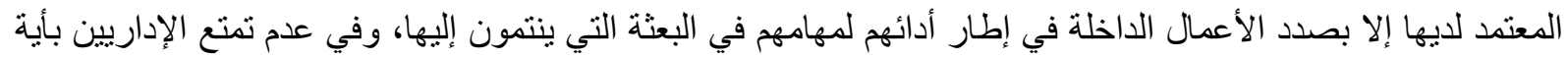

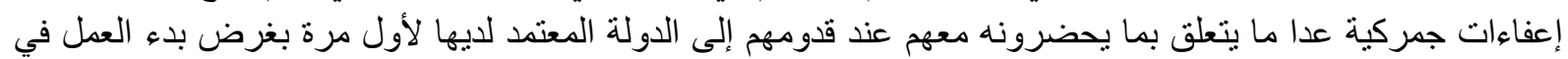

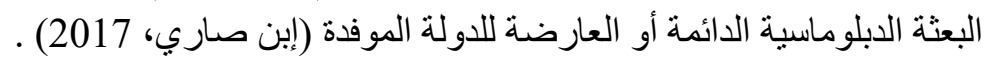

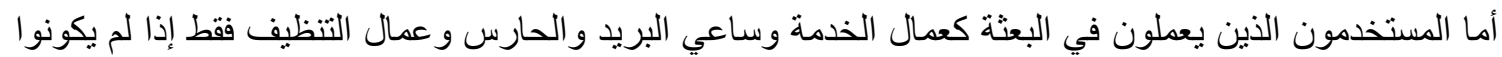

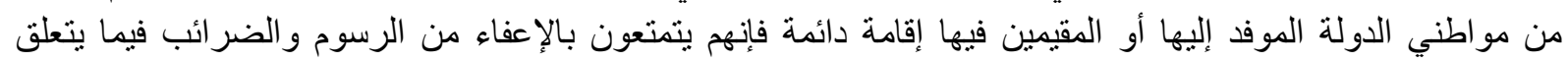

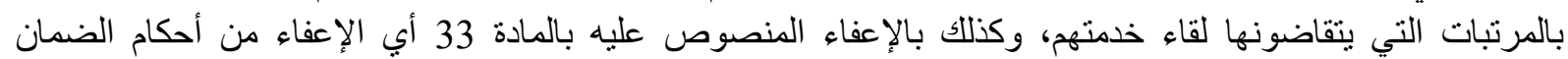
الاجتماعي (رحيمة، 2013-2014) و (ولي)

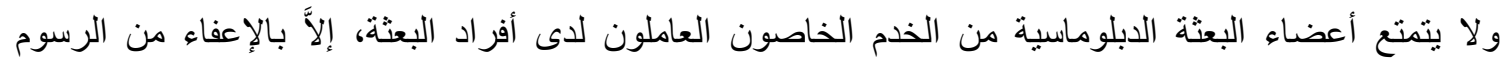

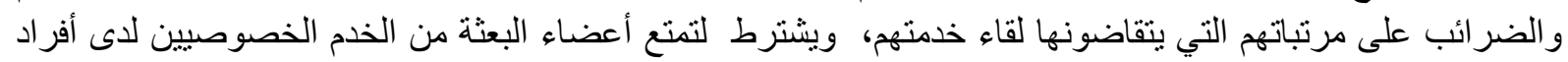

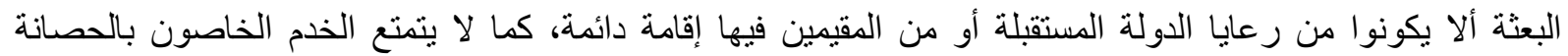

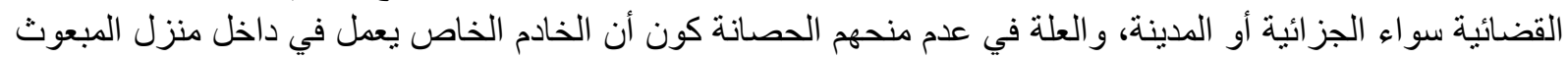

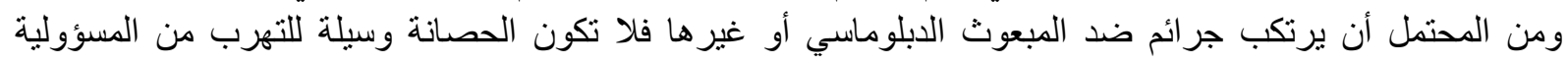

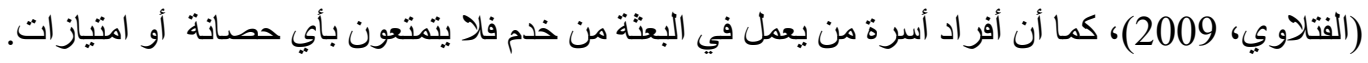

الخاتمة

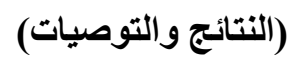

بعد الدراسة المستفيضة التي قمنا بها بشأن تسليط الضوء واته على حصانات وامتيازات المبعوث الدبلوماسي وهو

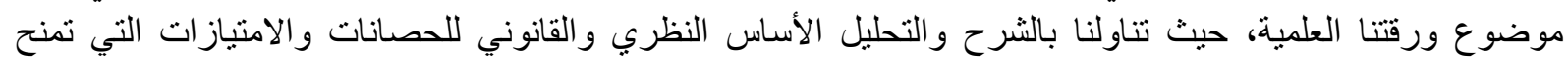

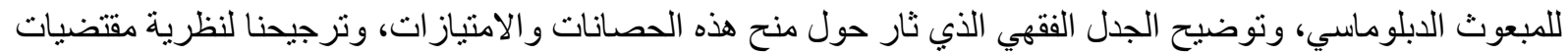

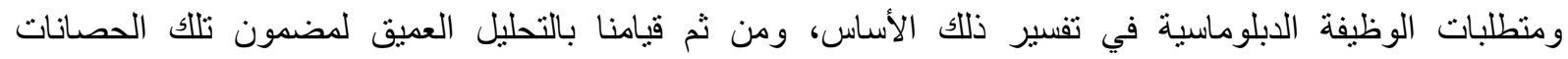

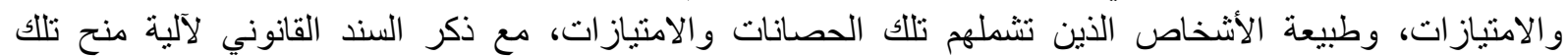

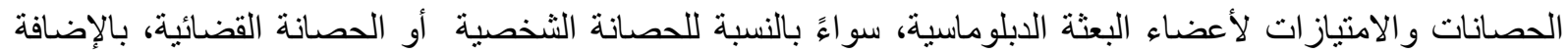

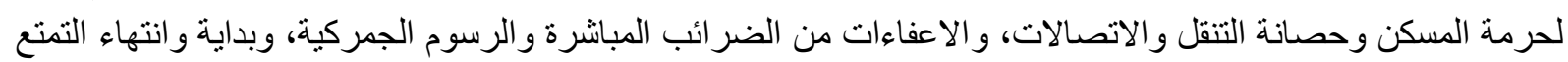

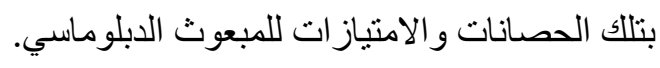
ولقد تم من خلال هذه الدراسة استخلاص العديد من النتائج والتوصيات على الوجه التالي: أولاً: النتائج:

1 إن الحصانات والامتياز ات الدبلوماسية لم تكن وليدة العصر الحالي، فمنذ القدم تمتع الدبلوماسيون بحماية تكفل لهم الأمان و الاطمينان.

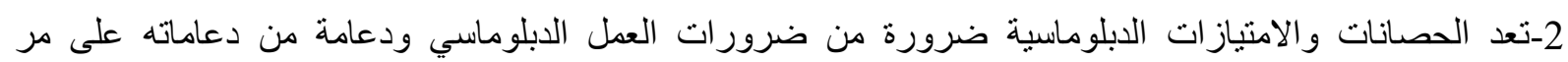

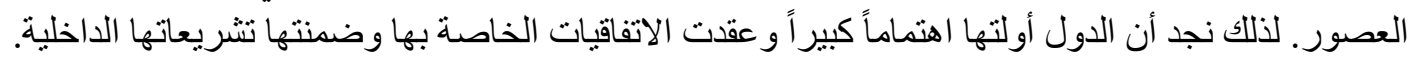

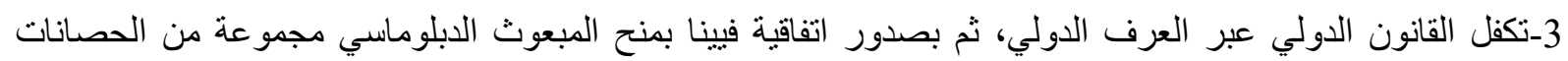
والامتياز ات الدبلوماسية من أجل القيام بعملهم بكل حرية و اطمئنان. 


$$
\begin{aligned}
& \text { 4-لاتمنح الحصانات والامتياز ات الدبلوماسية لشخص المبعوث الدبلوماسي و إنما بصفته الوظيفية، } \\
& \text { تسهيلاً لأداء مهمته التي تتسم بطابع الخصوصية التي تتمتع بها و لا يتمتع بها الموظفون العموميون. }
\end{aligned}
$$

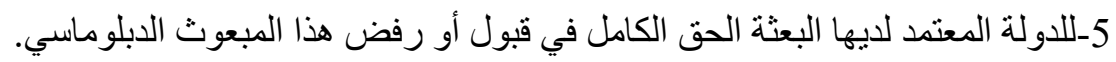

6-إن التمتع بالحصانات و الامتياز ات الدبلوماسية يختلف مداه بالنسبة لكل عضو من أعضاء البعثة الدبلوماسية تبعاً لمركزه

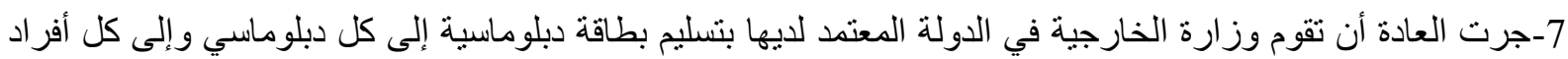

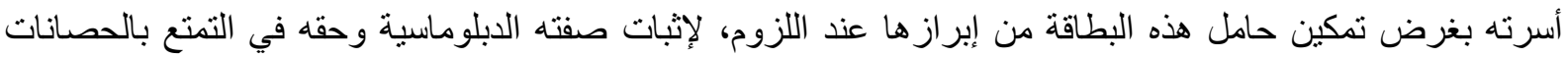
و الامتياز ات الدبلوماسية.

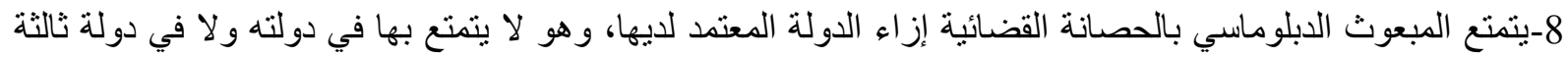

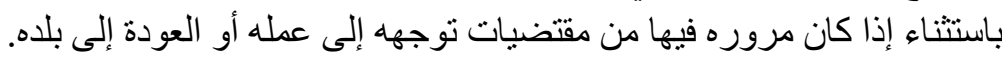

ثانياً: التوصيات:

1-يوصي الباحث الدول بكافة مؤسساتها على احترام العمل الدبلوماسي من خلال حماية واحترام كل ما يتعلق بالبعثة الدبلوماسية من شخص المبعوث الدبلوماسي ومقر البعثة والمباني الدبلوماسية الموجودة على على أراضيها عندما تكون دولة الدانة

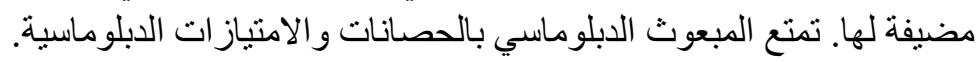

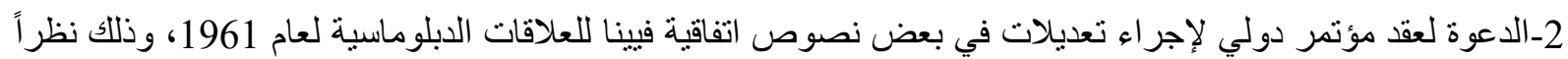

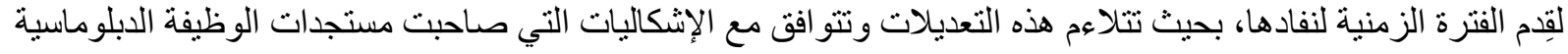

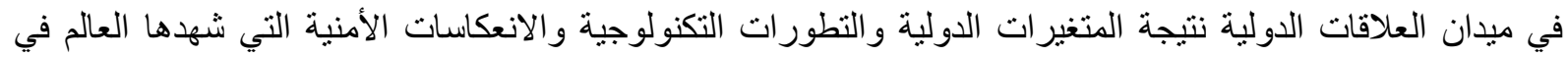

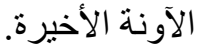


mattingly garrett. (1969). renaissance diplomacy. london: jonathan cape.

sir harlod, n. (1969). diplomacy. london: oxford university press.

$$
\begin{aligned}
& \text { إبر اهيم أحمد خليفة. (2007). القانون الدبلوماسي و القنصلي. الإسكندرية: دار الجامعة الجديدة. }
\end{aligned}
$$

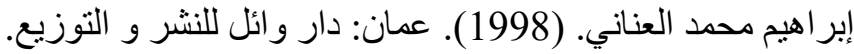

$$
\begin{aligned}
& \text { إبن منظور. (2000). اسان العرب. بيروت: (1961). عدان: دار الجبل. } \\
& \text { إتفاقية إتفاقية فيينا.(1961) . }
\end{aligned}
$$

بيداء علي ولي. (بلا تاريخ). الحصانة القضائية للمبعوث الدبلوماسي. الكويت، كلية القانون جامعة القادسية.

جرجس جرجس. (1996). معجم المصطلحات الفقهية و القانونية. بيروت: الثركة الثانية العالمبية للكتاب.

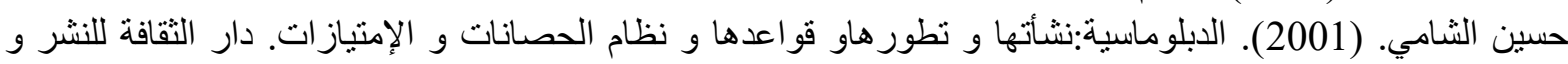

$$
\text { التوزيع و الإعلان. }
$$

رضوان إبن صاري. (2017). الحصانات و الإمنيازات الدبلوماسية و القنصلية. الجزائر: مجلة المنار للبحوث و الدر اسات القانونية و السياسية.

زايد مصباح عبيد الله. (2001). الدبلوماسية. طر ابلس: دارية.

سهيل حسين الفتلاوي. (2009). الدبلوماسية بين النظرية و التطبيق. عمانية.

شفيق عبد الرزاق السامر ائي. (2002). الدبلوماسية. طر ابلس: الجامعة المفتوحة.

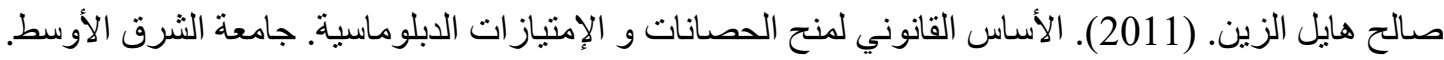

صلاح الدين عامر. (1995). مقدمة لدر اسة القانون الدولي العام. القاهرة: دار النهضة التانية العربية.

عاطف محمد علي الجعيدي. (12009). النظام القانوني الدولي لحصانة الدحفوظات و الواني الونائق الدبلوماسية. طر ابلس، أكاديمية الدر اسات العليا.

عبد الغني الصادق خليفة الأسود. (2011). حصانات و امنياز ات أعضاء البعثات الدبلوماسية الخاصة في ظل القانون الدولي العام. طر ابلس، أكاديمية الدر اسات العليا.

عبد القادر شعبان أبو أنور . (2016). و اقع الدبلوماسية البرلمانية الفلسطينية و مستقبلها. جامعة الأقصى.

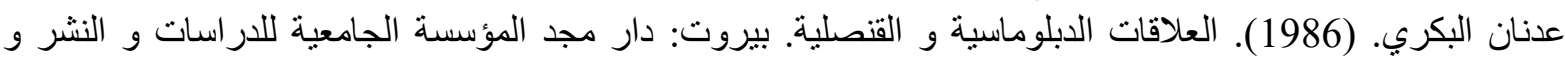

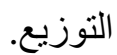

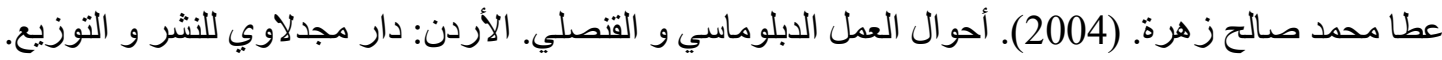

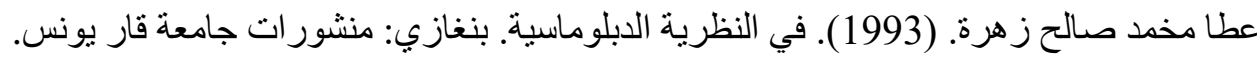
علاء أبو عامر. (2004). العلاقات الدولية الدبلوماسية و الإستراتيجية. عمان: دارية الإلية الثروق.

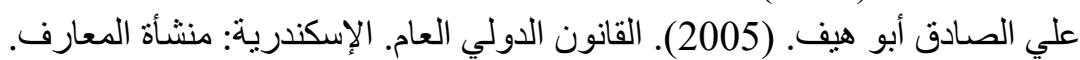
علي حسين الثامي. (1994). الدبلوماسية نشأتها و نطور ها و قو العد نظام الحصانات و الإمنياز ات الدبلوماسية. بيروت: دار العلم للملايين.

علي صادق أبو هيف. (1967). القانون الدبلوماسي. الإلإسكندرية: منشأة المعارف. علي صادق أبو هيف. (2005). القانون الدولي العام. الإسكندرية: منشأة المعارف. لإنية.

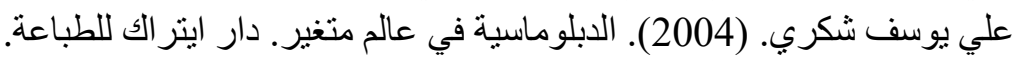
غازي صباريني. (1931).

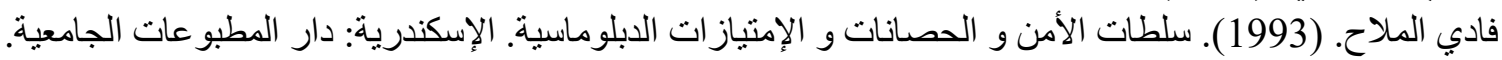

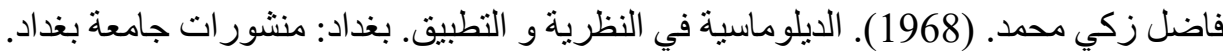
فؤ اد شباط. (1990). الدبلوماسية. دمشق: المطبعة التعاونية.

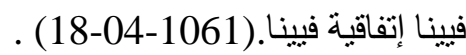

لاغش رحيمة. (2013-2014). سيادة الدولة و حقها في مباشرة في التمثيل الدبلوماسي. تلمسان، كلية الحقوق جامعة أبي بكر بلقايد، الجز ائر. 


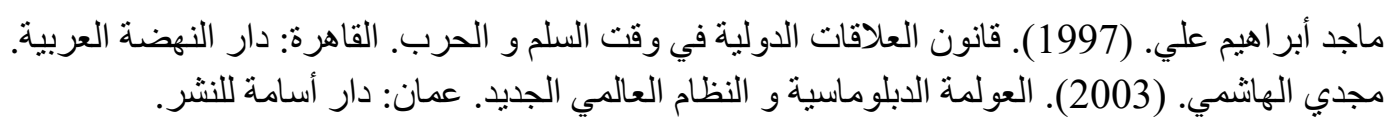

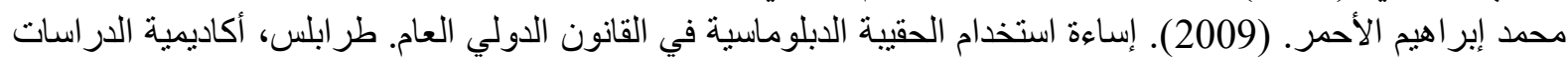
العليا.

منير عبد الرحمان ساسي الصابري. (2010). الحصانات الدبلوماسية و مقتضيات أمن الدولة الموفد إليها. طر ابلس، أكاديمية الدر اسات العليا.

ناظم عبد الواحد الجاسور. (2001). أسس و قواعد العلاقات الدبلوماسية و القنصلية. عمان: دار مجدلاوي للنشر و التوزيع.

نوري حامد مرعي شابيش. (2010). الحصانات و الامتياز ات الدبلوماسية في القانون الدولي. أكاديمية الدراسات العليا، طر ابلس.

وليد خالد الربيع. (بلا تاريخ). الحصانات و الإمتياز ات الدبلوماسية في الفقه الإسلاميو القانون المقارن. الكويت: مجلة الفقه و القانون المقارب. 